\title{
A Review of Basic Mechanical Behavior of Laminated Bamboo Lumber
}

\author{
Assima Dauletbek ${ }^{1}$, Haitao $\mathrm{Li}^{1,2, *}$, Rodolfo Lorenzo ${ }^{3}$, Ileana Corbi ${ }^{4}$, Ottavia Corbi ${ }^{4}$ and \\ Mahmud Ashraf ${ }^{5}$
}

${ }^{1}$ College of Civil Engineering, Nanjing Forestry University, Nanjing, 210037, China

${ }^{2}$ Joint International Research Laboratory for Bio-Composite Building Materials and Structures, Nanjing Forestry University, Nanjing, 210037, China

${ }^{3}$ University College London, London, WC1E 6BT, UK

${ }^{4}$ University of Naples Federico II, Naples, 80133, Italy

${ }^{5}$ Deakin University, Geelong, VIC 3216, Australia

*Corresponding Author: Haitao Li. Email: lhaitao1982@126.com

Received: 08 June 2021 Accepted: 28 July 2021

\begin{abstract}
Over the past decade, the physical and mechanical performances of laminated bamboo lumber (LBL)-a bamboobased structural material, have been extensively studied using experimental, analytical, and numerical approaches. This paper presents a review of existing knowledge in the literature about the mechanical properties of LBL. The paper involved the review of the response of LBL to different types of loading such as tension, bending, compression, and shear. Based on results of the literature reviewed, the strength of LBL parallel to grain was 90-124 MPa with MOE of $10700 \mathrm{MPa}$ in tension, 29.55-72.60 MPa, and MOE of 8396-11022 MPa in compression, 63.87128.4 MPa, and MOE of 8320-10912 MPa in bending, and 7.15-17.5 MPa in shear. The average strength of LBL was similar and in some cases exceeded the average values of bamboo- or wood-based materials, while the variability of its mechanical parameters was lower. The variability in strength values of LBL was affected by bamboo species, density and thickness of bamboo strips, growth portion, type of treatment, strips arrangements, and type of adhesive which in turn calls for classification of LBL by strength grades, degree of hardness, the capability of impregnation and penetration, as well as by areas of application in construction. The study provided and discussed concluding observations, the current research gap, and future research directions on the mechanical properties of LBL.
\end{abstract}

\section{KEYWORDS}

Laminated bamboo lumber; mechanical properties; composites

\section{Introduction}

With the improvement of living standards, the demand for environmentally friendly, lightweight, and safe structures has increased dramatically [1-5]. Bamboo as a sustainable alternative to traditional building materials, including wood, has started to gain attention [6-15] due to its short time to harvest $[16,17]$, the variety of species, as well as the high yield, and the ability to reach a maximum height of 15-30 meters in 2-4 months, and the maximum strength in 3-8 years [18,19]. According to life-cycle 
assessment (LCA) results, bamboo is included in the "factor 20", which means that its impact on the environment is 20 times less compared to modern alternatives [19,20]. Simply put, the sustainability of bamboo-based building materials is conditioned by relatively fast harvesting, a more efficient rate of carbon sequestration compared to wood species, as well as low-energy processing, which creates minimal environmental impact.

Bamboo in its natural form has attractive mechanical properties, for instance, Moso bamboo (Phyllostachys pubescens) has a relative density ranging from 0.553 to $1.006 \mathrm{~g} / \mathrm{cm}^{3}$, the mean longitudinal tensile modulus of elasticity (MOE) from 8.987 to $27.397 \mathrm{GPa}$, and the mean longitudinal tensile strength from 115 to $309 \mathrm{MPa}$ [21]. The tensile strength of mature bamboo is comparable to mild steel [22], the strength and stiffness are higher than those of wood products, and its strength-to-weight ratio is higher than that of wood, cast iron, aluminum alloys, and structural steel [23-25]. For decades, it has been widely used in furniture, bridges, and buildings. Due to good integrity, the bamboo structure does not damage in small earthquakes nor collapse in violent ones [26-28]. As a hollow tube, the original bamboo copes well with bending loads due to a large ratio of moment of inertia to a cross-sectional area [19].

Initially, it was difficult to use it in joints and flat applications due to its shape. To address this task, engineered bamboo such as laminated bamboo lumber (LBL), and related materials as glued laminated bamboo (glubam), parallel strand bamboo (PSB), etc., have been developed and can be manufactured in various shapes and sizes for different applications [29,30]. Recently, engineered bamboo materials have been increasingly used as structural and non-structural materials in many areas due to unique flexibility, good environmental, physical, and mechanical characteristics that are comparable to timber and gluelaminated timber products [31-37]. For instance, glubam can be widely applied in composite structures such as reinforced bar, due to improvement of the ultimate bearing capacity of the bending components in timber structures; as well as bamboo-steel composites or bamboo reinforced concrete can reduce the mass of the structures [26]. In cold regions, the thermal performance of bamboo structures decreases energy demand by $65 \%$, as well as gypsum boards and rock wool used in glubam prevent fire spread and the conduction of high temperature [26]. The Asian region has made some progress in the development of bamboo materials with China taking the lead in LBL production [38]. Extensive research has been done to determine the feasibility of LBL in structural applications, such as beams to columns and other connections [39-44], as well as sheathing panels made of LBL [45,46]. Ramage et al. [47] reviewed the published research on bamboo scrimber and LBL and compared them to structural timber and laminated veneer lumber (LVL). Gatoo et al. [48] described the existing national and international codes to consider the development of comprehensive standards for LBL similar to those in use for timber. Disen et al. [49] made an overview of the current state of full culm bamboo connections. However, there is no review of existing research that covers the basic mechanical properties of the material. So, this study aims to present a review of the basic mechanical performance of LBL. The paper involves the review of the response of the LBL material to different types of loading.

According to the Science Direct database, until 2000, only a few studies on LBL were conducted, in the period from 2000 to 2005, the number of studies increased to 21. From 2006 to 2010, the number of studies was the same as in previous years, accounting for 26 papers. Starting from 2011, there has been a drastic increase in research, and by 2015 , published papers on laminated bamboo constituted 161 . One of the main reasons for the increase in interest in bamboo as a building material is the transition of the World Development Goals to a sustainable way. Between 1982 and 2012, international Earth Summits were held; Agenda 21 and Agenda 30 were signed in 2012 and 2015, respectively, calling for a sustainable form of development with a reduction in energy consumption and energy-induced carbon emissions. In turn, Architecture, Engineering, and Construction (AEC) sector practitioners and engineers turned their attention to the development of new environmentally friendly alternatives that would replace traditional 
energy-intensive materials such as cement and steel. Over the past 5 years, the trend has continued, and the number of articles today is 520 (Fig. 1).

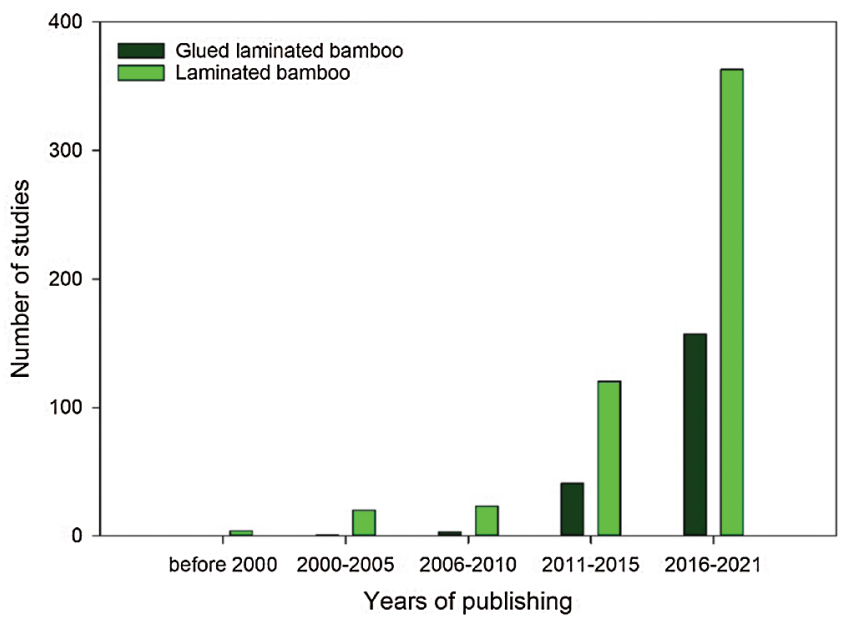

Figure 1: Existing research on "laminated bamboo" and "glued laminated bamboo" query per year via Science Direct

The boundary of the search covered the journals and conference papers, while book chapters, letters, notes, and short communications were removed according to the requirements. The requirements ensuring the consistency are: (1) an article is written in English; (2) published in a journal or conference proceedings; (3) include experimental, analytical, or numerical investigation; (4) the main focus of the article is to explore the mechanical behavior of LBL. Finally, 24 papers were adopted for review, from which 22 papers are published in the last 10 years, and 2 papers are of the 2002 and 2007 years. The review is not comprehensive and includes selected publications that focus on the investigation of the basic mechanical properties of small-sized LBL material rather than structural LBL applications. A summary of the selected studies is presented in Tab. 1.

Table 1: Summary of selected studies on LBL

\begin{tabular}{|c|c|c|c|c|c|c|c|c|}
\hline Study & Species & Origin & Glue & $\begin{array}{l}\text { The glue } \\
\text { spread rate, } \\
\mathrm{g} / \mathrm{m}^{2}\end{array}$ & $\begin{array}{l}\text { Lamination } \\
\text { method }\end{array}$ & Test standard & Test type & Size, $\mathrm{mm}$ \\
\hline \multirow[t]{4}{*}{ Chen et al. [34] } & Phyllostachys & China & $\mathrm{PF}$ & - & Hot pressed & ASTM D143 & Compression \| & $50 \times 50 \times 200$ \\
\hline & pubescens & & & & & & Tension \| & $25 \times 50 \times 453$ \\
\hline & & & & & & & Bending & $50 \times 50 \times 760$ \\
\hline & & & & & & & Shear II & $50 \times 50 \times 62$ \\
\hline \multirow{6}{*}{$\begin{array}{l}\text { Sharma et al. } \\
{[35]}\end{array}$} & Phyllostachys & China & $\mathrm{PF}$ & - & - & EN 408 & Bending & $90 \times 140 \times 2440$ \\
\hline & pubescens & & & & & & Compression \| & $90 \times 140 \times 540$ \\
\hline & & & & & & & Compression $\perp$ & $45 \times 70 \times 90$ \\
\hline & & & & & & & Tension ॥ & $18 \times 140 \times$ \\
\hline & & & & & & & & 2440 and \\
\hline & & & & & & & & $30 \times 90 \times 1520$ \\
\hline
\end{tabular}




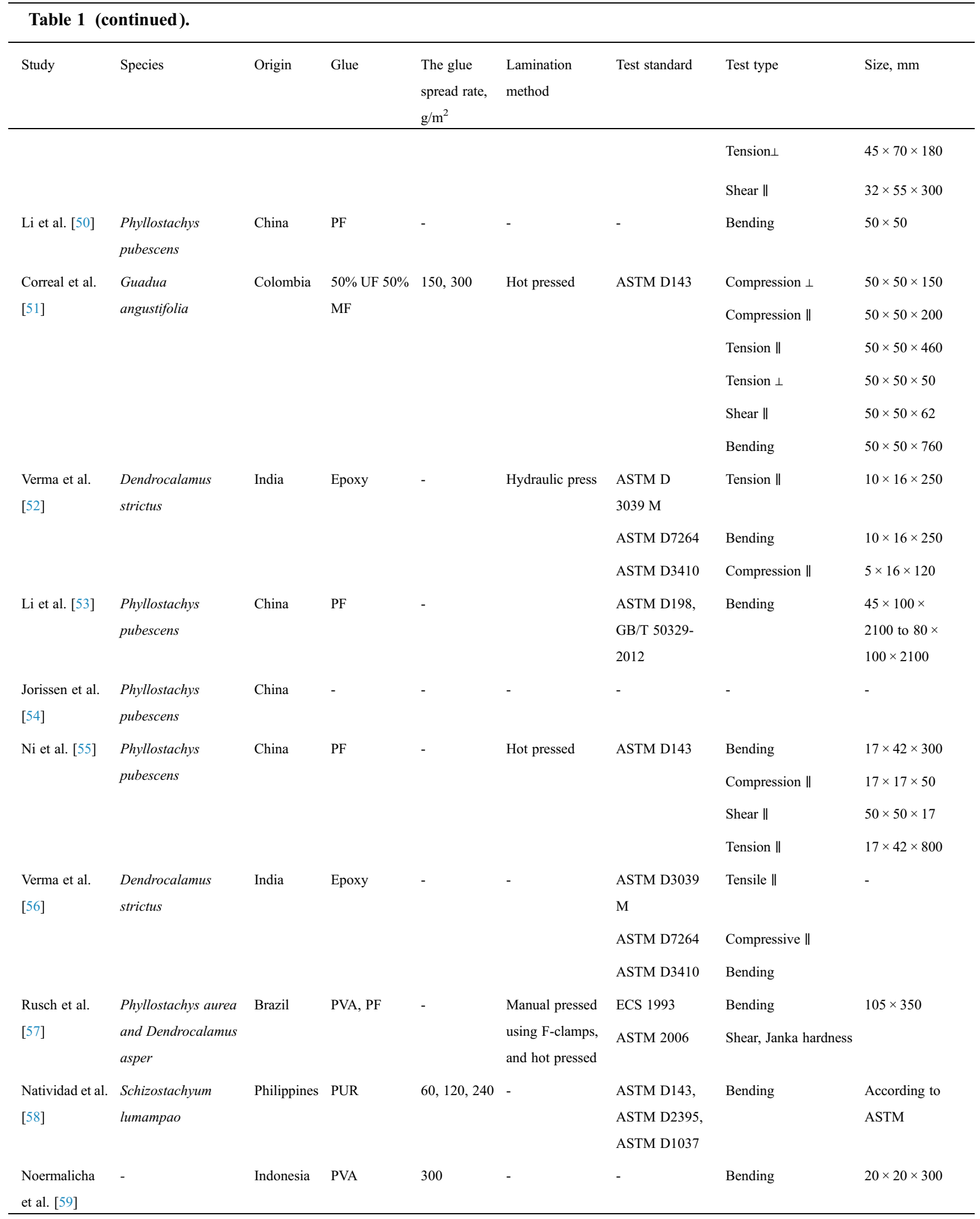


JRM, 2022, vol.10, no.2

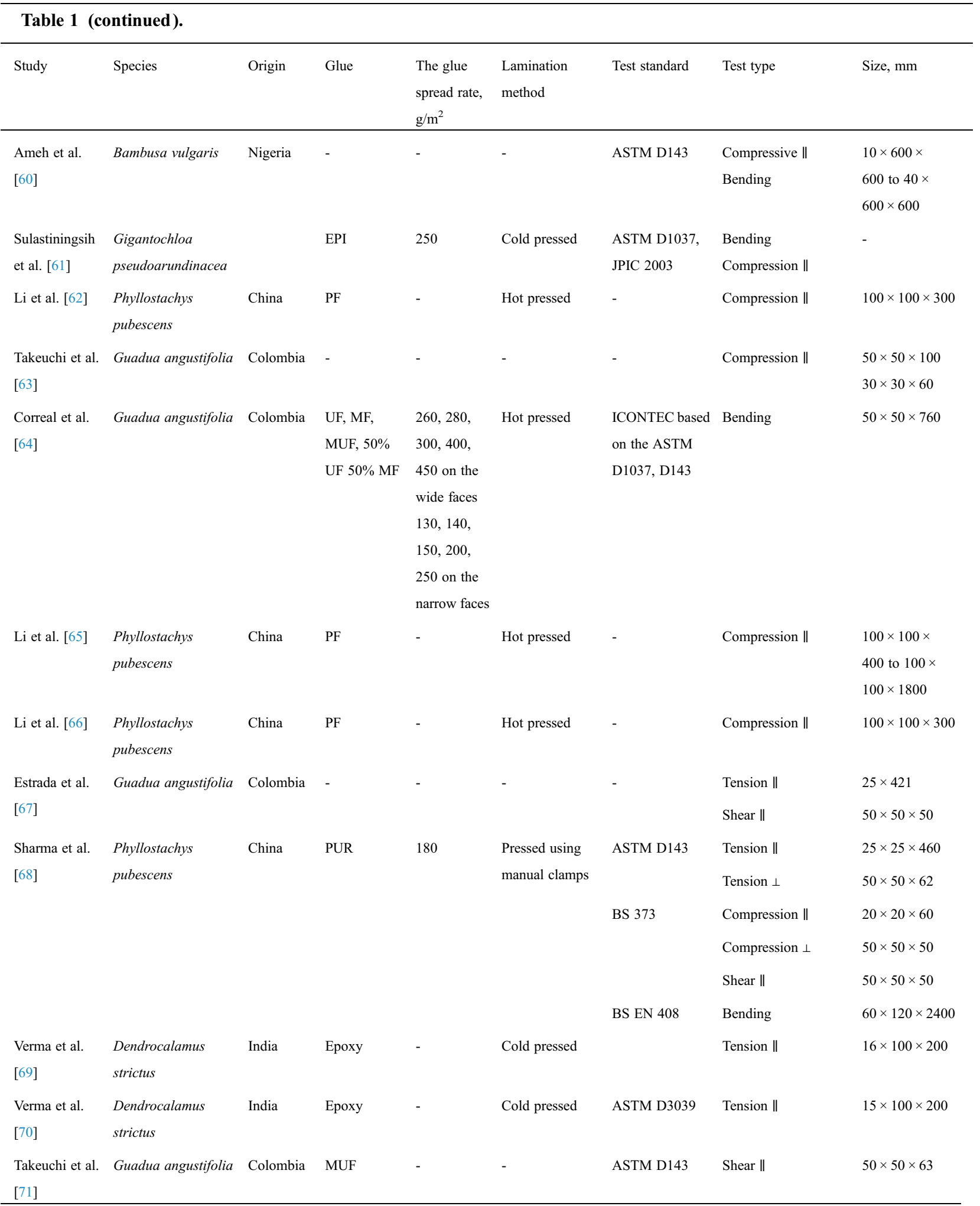

Note: Adhesives: PF-phenol-formaldehyde, UF-urea-formaldehyde, MF-melamine-formaldehyde, PVA-polyvinyl acetate, MUFmelamine-urea-formaldehyde, PUR-polyurethane, EPI-polymer-isocyanate. 


\section{Production of $\mathbf{L B L}$}

Due to the orientation consistency of the vascular tissues and parenchyma tissues, as well as the absence of piths and transverse rays, the production of engineered bamboo is relatively convenient [33]. Based on the studies reviewed, bamboos from the genera Phyllostachys, Dendrocalamus, Bambusa, Guadua, and Gigantochloa are most often used for the production of LBL. Bakar et al. [72] reviewed the three processing methods for LBL production, including split-squaring (SS), v-grooving (VG), and split-edging (SE). SS method is cutting bamboo culms with nodes and internodes into $100 \mathrm{~cm}$ lengths and splitting them into $2 \mathrm{~cm}$ wide splits, then planning to remove the inner and outer parts of the splits and to produce strips of uniform thickness and width. VG is removing nodes with a circular saw to use only internodes, which then are grooved as described by Bakar et al. [73]. When the last groove is cut through, the culm opens to be coated with PVA and flattened overnight by the press. SE is cutting culms with nodes and internodes into $100 \mathrm{~cm}$ lengths and then splitting them with a machete into $2 \mathrm{~cm}$ wide splits which glued edge-to-edge using PVA to get a wide sheet. Then, the sheet is planned to obtain a uniform size. According to Mahdavi et al. [19], flattening is carried out at a pressure of $690 \mathrm{kPa}$ for 1-4 min. However, the flattening part can cause cracks to appear on bamboo culms [74].

Usually, the processing of LBL involves 4-5-year-old bamboo culms, that are cut into long strips with dimensions of $2000 \times 3 \times 15 \mathrm{~mm}$, dried till the moisture content gets $8-12 \%$, then planned to remove the wax and silica on the outer skin and inner cavity layer to get a uniform size of the strips [75-82]. Then, bamboo strips undergo one of two processes for treatment: bleaching or caramelization [68,83,84]. During bleaching, bamboo splits are treated in a hydrogen peroxide bath at $70-80^{\circ} \mathrm{C}$ and used for material which is called natural bamboo in the market. Caramelization is caramelizing the sugars in the bamboo splits using pressurized steam at $120-130^{\circ} \mathrm{C}$ to obtain the deeper brown color for a material which is commercially called caramelized or carbonized bamboo. According to Sharma et al. [68] and Reynolds et al. [85], the processing methods had an effect on the mechanical properties of LBL, which should be considered to determine its appropriate structural applications. After treatment, the strips are glued with adhesive, and cold- or hot-pressed to obtain a dimensionally perfect LBL. It should be noted that when using hot pressing for molding bamboo panels, densification can occur, which leads to an improvement in the mechanical properties of the material due to the destruction of the cell cavities or filling the pores and therefore reducing the volume fraction of voids [86]. According to Sinha et al. [87], strips are usually glued and pressed vertically, and therefore, the dimension and orientation are the same relative to the tangential and radial direction of bamboo. Fig. 2 shows the general manufacturing process of LBL.

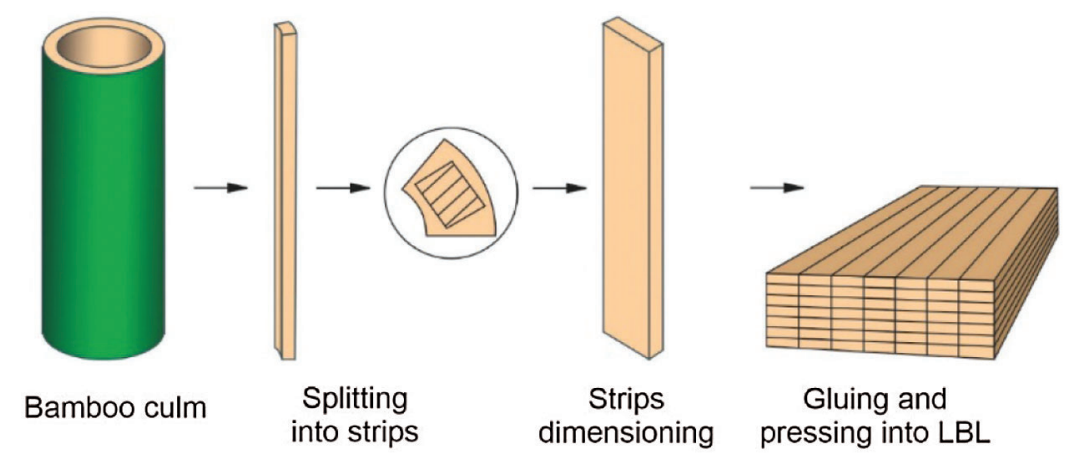

Figure 2: The manufacturing process of LBL

PF is most often used as an adhesive material. According to past studies, the type of glue had an impact on the physical and mechanical characteristics of the material. For example, based on the strength of the 
adhesion, MUF, as well as PF, would serve as the best option for LBL compared to EPI, PUR, hybrid polymer adhesive (HPA), and PVA [87]. At the same time, PF coped better in the exterior applications due to its low wettability, while PVA was recommended for use in the interior, where there was less contact with water [88]. Sinha et al. [89] pointed out the importance of the glue type in the production of LBL for structural applications, in particular full-sized beams, because they collapsed in the form of LBL delamination since the EPI glue used in the production of LBL could not transmit stress, and cracks appeared between the layers of LBL. The amount of glue used to produce LBL is often determined by the manufacturer. According to several studies, the glue spread rate appeared to be a significant variable for the internal bond strength [90], therefore, it was necessary to determine an optimum amount of spread rate for each type of glue.

The small LBL is produced from dried bamboo strips, assembling and gluing them into rectangular cross-sections [75], while large-scale LBL is made from lengthened bamboo strips with joints [91]. During the manufacturing process of LBL, defects of raw bamboo are removed or distributed randomly among the structural elements [34]. As a result of production processes, the obtained material is uniform and stable in size with mechanical performance that makes it competitive with traditional building materials [43]. However, the manufacturing process of LBL is intense [87], and the cost of the final product is more expensive than the alternatives [19].

Li et al. [92] investigated the environmental impact of the production of LBL and concluded that acidification and ozone depletion potentials were significantly affected by emissions from UF due to the content of urea. According to the results, carbonization, drying, and hot pressing significantly increased eutrophication, photochemical ozone generation, and acidification due to the consumption of electricity coming from fossil fuels and emissions from oxynitrides, arenes, etc. However, the study did not cover the comparison of energy demand potential and other environmental indicators of LBL with LCA results of similar bamboo- and wood-based materials. According to Yang et al. [41] and Xiao et al. [93], the total energy consumption of similar bamboo-based material glubam was $2.67 \mathrm{GJ} / \mathrm{m}^{3}(3.14 \mathrm{GJ} / \mathrm{ton})$ which was $75 \%$ lower compared to cement with $11.0 \mathrm{GJ} / \mathrm{m}^{3}$ (4.58 GJ/ton) and steel with $448.0 \mathrm{GJ} / \mathrm{m}^{3}$ (57.4 GJ/ton), but higher than timber with $1.2 \mathrm{GJ} / \mathrm{m}^{3}$. Similarly, carbon dioxide emission of glubam constituted $-261 \mathrm{~kg} / \mathrm{m}^{3}$, which was lower than that of cement with $2040 \mathrm{~kg} / \mathrm{m}^{3}$, aluminum with $6325 \mathrm{~kg} / \mathrm{m}^{3}$, and steel with $8117 \mathrm{~kg} / \mathrm{m}^{3}$, but higher than that of timber with $-228 \mathrm{~kg} / \mathrm{m}^{3}$, and plywood with $-168 \mathrm{~kg} / \mathrm{m}^{3}$ of $\mathrm{CO}_{2}$ emissions, respectively. Addressing these challenges, Mahdavi et al. [94] proposed a simple, practical, and low-technology approach for LBL fabrication with mechanical properties comparable to other similar laminated bamboo and wood products. However, a complete LCA of LBL and comparative study of the environmental impact of LBL and conventional materials are still necessary. And the development of low-energy methods for the production of LBL using environmentally friendly adhesives remains relevant.

\section{Review of Basic Mechanical Properties of LBL}

In this article, an overview of existing studies on the basic mechanical properties of LBL has been conducted. The study raised the following research question: what are the basic mechanical properties of LBL in terms of tensile, compression, bending, shear testing considering small specimens. Fig. 3 shows the schematic of mechanical tests involved in the investigation of mechanical behavior of LBL in reviewed studies.

\subsection{Bending}

The bending performance of the LBL material has been discussed in many studies. Different factors that may affect the mechanical performance were taken into account, such as bending directions, length, and width of the specimen, etc. Fig. 4 shows the bending directions characterized by the arrangement of the bamboo strips in typical LBL specimens (Fig. 4a). For example, in the radial bending direction (RBD or 
flatwise), the load is distributed along the radially arranged bamboo strips (Fig. 4b), in the tangential bending direction (TBD or edgewise)-the load is directed along the tangentially arranged bamboo strips (Fig. 4c).

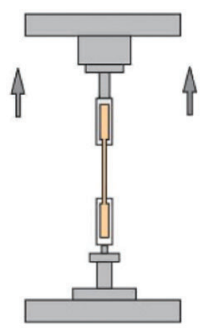

(a)

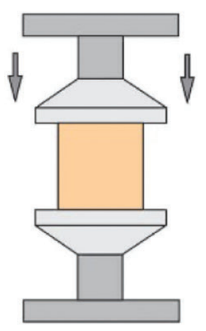

(d)

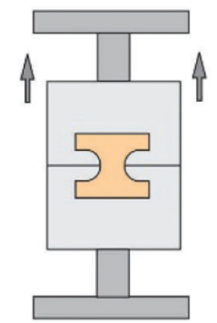

(b)

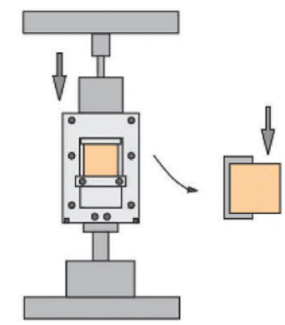

(e)

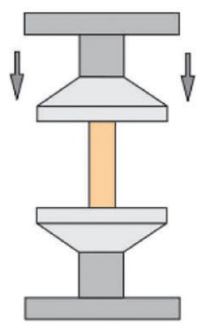

(c)

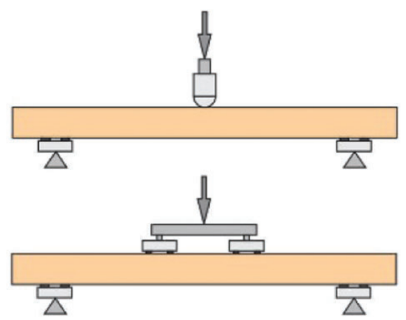

(f)

Figure 3: Test schematic for investigation of mechanical performance of LBL: (a) tension parallel to grain; (b) tension perpendicular to grain; (c) compression parallel to grain; (d) compression perpendicular to grain; (e) shear parallel to grain; (f) three- and four-point bending

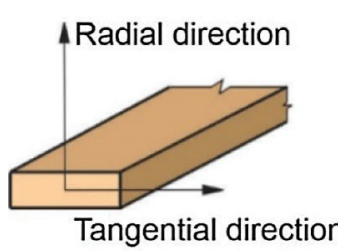

(a)

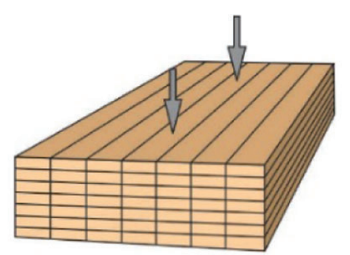

(b)

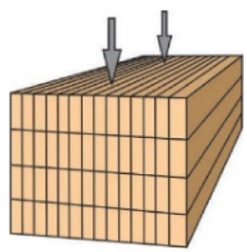

(c)

Figure 4: Bending direction: (a) two directions for a strip; (b) radial bending direction (RBD or flatwise); (c) tangential bending direction (TBD or edgewise)

Both flatwise and edgewise, small LBL specimens showed a similar failure mode under bending, which was characterized by fracture of the outer layer fibers (Fig. 5) [34,50,51].

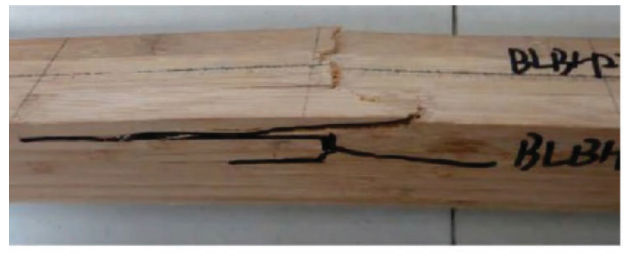

(a)

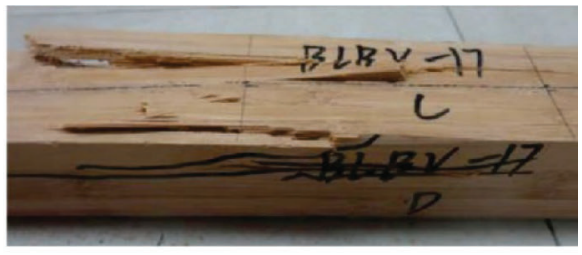

(b)

Figure 5: Failure modes for bending tests: (a) for RBD specimens, (b) for TBD specimens (extracted from Li et al. [50] paper) 
Based on the results of the study, the effect of the length on the static bending strength of LBL was insignificant, but the MOE showed an increase with the increase in the length of the specimen [50]. According to Verma et al. [52], the destruction of the specimen on the bottom tensile part occurred due to the rupture of the matrix and fibers, while the compression side collapsed due to micro-buckling. At the same time, some specimens exhibited delamination due to the fracture of resin during loading (Fig. 6) [52].

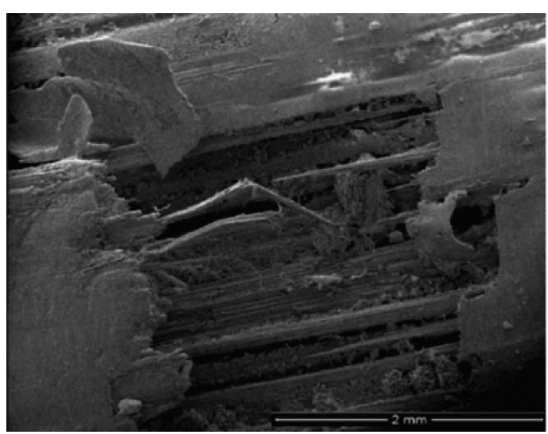

(a)

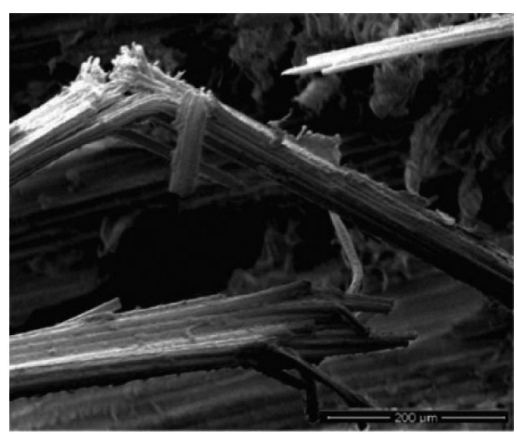

(b)

Figure 6: SEM photographs 70x (a) and 500x (b) of the fractured lateral surface of specimens tested in flexure (extracted from Verma et al. [49] paper)

According to the literature, all the tested specimens exhibited linear behavior up to the yield point, followed by a nonlinear deformation [34], and failed in the plastic-elastic stage. Therefore, the design load of LBL with a rectangular section was controlled by stiffness rather than strength [34,50]. Based on test results, Li et al. [53] proposed a model for the stress-strain relationship of LBL under bending as shown in Fig. 7.

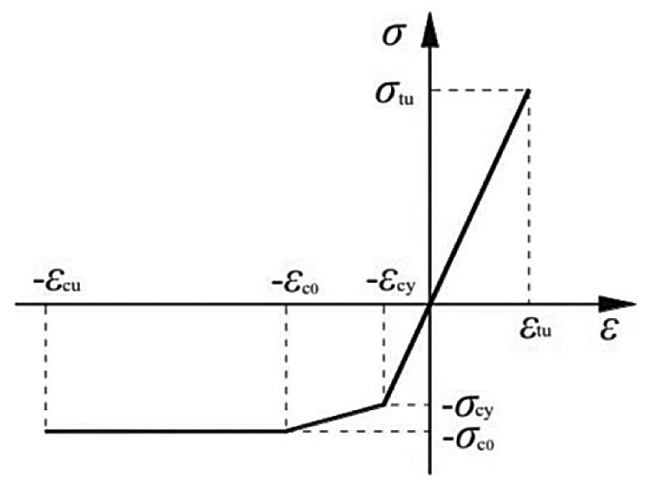

Figure 7: Stress-strain relationship of LBL under bending (extracted from Li et al. [53] paper)

The results showed that the MOE and bending strength of RBD specimens were about $10 \%$ higher than those of TBD and could therefore be ignored. It should be noted, that the presence of nodes and joints significantly affected the bending performance of the LBL units, being weak points under tension and the main initiators of failure. For instance, the nodes and edge butt joints reduced the ultimate bearing capacity, flexural strength, MOE, and modulus of rupture (MOR) of LBL [54,55].

$\mathrm{Ni}$ et al. [55] considered the dependence of the bending strength of LBL on the density grades of the bamboo strips indicated in Tab. 2 and found that the MOR ranged from 85 to $115 \mathrm{MPa}$, while the 
corresponding MOE was distributed in the interval of 7.67 to $10.15 \mathrm{GPa}$ with an increase in the density of bamboo (Fig. 8).

Table 2: Nine-grade density standard for dimension bamboo strips

\begin{tabular}{llllllllll}
\hline Grades & 9 & 8 & 7 & 6 & 4 & 5 & 3 & 2 & 1 \\
\hline Densities $\left(\mathrm{g} / \mathrm{cm}^{3}\right)$ & $0.5-0.55$ & $0.55-0.6$ & $0.6-0.65$ & $0.65-0.7$ & $0.7-0.75$ & $0.75-0.8$ & $0.8-0.85$ & $0.85-0.9$ & $0.9-0.95$ \\
\hline
\end{tabular}

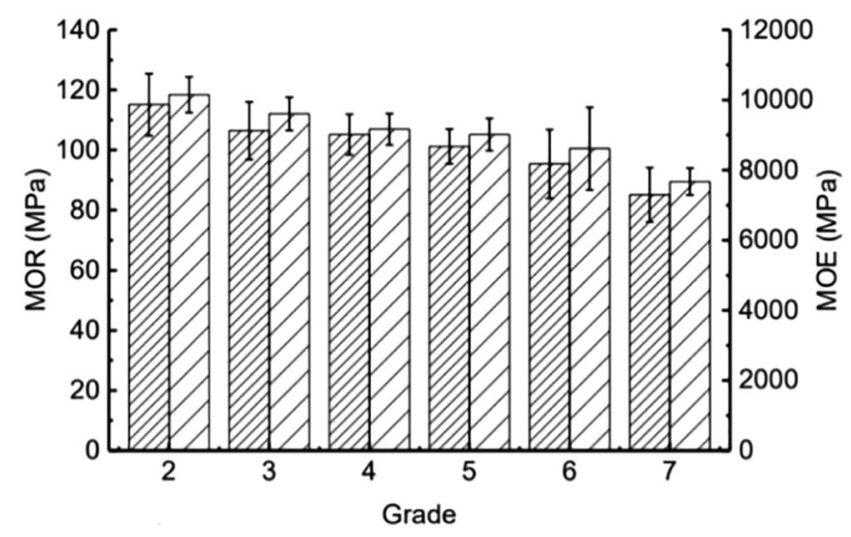

Figure 8: MOR and MOE of different grades of LBL (extracted from Ni et al. [55] paper)

Since the density of bamboo affected the bending strength of the final LBL product, the grading method by the density of bamboo strips should be taken into account as a controlling factor of the variability of LBL. Verma et al. [56] pointed out the correlation between the height of bamboo culm and mechanical properties. According to the results, the bending strength increased with an increase in height with values from 109.33 $\mathrm{MPa}$ to $165.6 \mathrm{MPa}$ and decreased from the outer to inner region with values from 109.33 MPa to 95.66 MPa. Rusch et al. [57] compared bending performance of LBL made of two types of species: Phyllostachys aurea and Dendrocalamus asper and concluded that the mean values for MOR, MOE, the shear glued line, and Janka hardness of $D$. asper were $135.2 \mathrm{MPa}, 13059 \mathrm{MPa}, 4.12 \mathrm{MPa}$, and $3812 \mathrm{~N}$, while for $P$. aurea, the same parameters were $99.4 \mathrm{MPa}, 12746 \mathrm{MPa}, 0.81 \mathrm{MPa}, 1647 \mathrm{~N}$, respectively. This in turn verified the significant difference among species of bamboo.

Natividad et al. [58] examined the arc-layered laminated bamboo (ALBL) and concluded, that ALBL with a glue spread rate of $120 \mathrm{~g} / \mathrm{m}^{2}$ had the best physical and bending properties. However, this type of LBL was not recommended for structural use since it could not satisfy the $80 \mathrm{MPa}$ minimum requirement for MOR. Considering the arc-shape of laminas, Jimenez Jr et al. [95] investigated the effect of species and glue spread rates and figured out that, B. blumeana had better physical properties than G. levis and $80 \mathrm{~g} / \mathrm{m}^{2}$ glue spread rate was better for both species and both glue types-PVA and PUR. Noermalicha et al. [59] pointed out the influence of the thickness of laminas and the presence of nodes on the mechanical properties of LBL made of curved laminas. Based on test results, laminas with $4 \mathrm{~mm}$ thickness showed the optimum values, however, compared to straight laminas, curved ones had low bending properties.

Ameh et al. [60] investigated the effect of the thickness of the LBL board (10 mm, $20 \mathrm{~mm}, 40 \mathrm{~mm})$ and strip position in the culm of bamboo (top, middle, bottom) and concluded, that the middle and top parts had the highest impact on bending strength constituting $33.66 \mathrm{MPa}$ and $27.94 \mathrm{MPa}$ respectively, while MOR increased from the top to the bottom and was $56.7 \mathrm{MPa}, 62.33 \mathrm{MPa}$, and $76.43 \mathrm{MPa}$, respectively. However, there were no significant changes in thermal properties for different thicknesses of LBL. 
According to Sulastiningsih et al. [61], the presence of nodes in the bamboo strips did not affect the MOR of LBL with values varied from 95.2 MPa to $117.48 \mathrm{MPa}$, but the thickness swelling of LBL was significantly reduced due to the presence of nodes in the bamboo strips. The authors suggested that the complexity of the structure of the nodes' vascular cells makes it possible to create denser and harder materials that are resistant to wettability.

Tab. 3 shows the comparison of mechanical properties of LBL small specimens under bending compared to other bamboo- and wood-based materials.

Table 3: Bending performance of LBL material compared to similar bamboo- and wood-based materials

\begin{tabular}{|c|c|c|c|c|c|c|}
\hline Material & Species & Size, $\mathrm{mm}$ & $\begin{array}{l}\text { Bending } \|, \\
\mathrm{MPa}\end{array}$ & $\begin{array}{l}\text { Bending } \perp \text {, } \\
\mathrm{MPa}\end{array}$ & $\begin{array}{l}\text { MOE ॥, } \\
\text { MPa }\end{array}$ & $\begin{array}{l}\mathrm{MOE} \perp, \\
\mathrm{MPa}\end{array}$ \\
\hline $\begin{array}{l}\mathrm{LBL} \\
{[34,50,53-55]}\end{array}$ & $\begin{array}{l}\text { Phyllostachys } \\
\text { pubescens }\end{array}$ & $\begin{array}{l}50 \times 50 \times 760 \\
50 \times 50 \times 420 \text { to } \\
50 \times 50 \times 760 \\
45 \times 100 \times 2400 \text { to } \\
80 \times 100 \times 2400 \\
17 \times 42 \times 300\end{array}$ & $63.87-128.4$ & - & $8320-10912$ & - \\
\hline LLBC $[52,96]$ & $\begin{array}{l}\text { Dendrocalamus } \\
\text { strictus }\end{array}$ & $10 \times 16 \times 250$ & 100.8 & - & 12420 & - \\
\hline PSB [97] & - & $160 \times 110 \times 1880$ & $89.32 \pm 4.92$ & & $12656 \pm 763.94$ & \\
\hline Glubam $[93,98]$ & - & - & 99 & - & $10500-11200$ & - \\
\hline $\begin{array}{l}\text { Bamboo scrimber } \\
\text { [99] }\end{array}$ & $\begin{array}{l}\text { Phyllostachys } \\
\text { pubescens }\end{array}$ & $140 \times 140$ & 119 & - & 13000 & - \\
\hline LVL [100] & Douglas-fir & - & $54.2-71.7$ & - & $15400-19300$ & - \\
\hline Glulam [101] & Douglas-fir & - & 48.74 & - & 15370 & - \\
\hline WPC [102] & Pine & $4 \times 10 \times 67$ & 26.1 & 16.7 & 4100 & 2660 \\
\hline Plywood [100] & Redwood & - & $33.72-42.61$ & - & $6960-8550$ & - \\
\hline OSB [100] & $\begin{array}{l}\text { Southern } \\
\text { Pine }\end{array}$ & - & 23.8 & 24.2 & 4410 & 2.89 \\
\hline Douglas-fir [100] & & - & 85 & - & 13400 & - \\
\hline Teak [100] & & - & 80 & - & 9400 & - \\
\hline
\end{tabular}

Note: Materials: LLBC-layered laminate bamboo composite, PSB-parallel strand bamboo, LVL-laminated veneer lumber, WPC wood plastic composite, OSB-oriented strand board.

It could be seen that the bending strength of LBL is comparable with similar bamboo-based materials, such as LLBC, glubam, or bamboo scrimber, as well as with wood-based materials such as Douglas-fir or teak. At the same time, the bending strength of LBL is relatively superior to LVL, glulam, and WPC. The variability of the LBL can be associated with the use of different species of bamboo, adhesives, and specimens' sizes. MOE of LBL significantly lags behind the conventional wood laminates, like glulam and LVL, as well as bamboo scrimber, the rigidity of which has been much higher since more force is required for its deformation. 


\subsection{Compression}

The destruction of the LBL material in compression parallel and perpendicular to grain occurred due to the fracture of the fibers or matrix, which took place in the matrix or at the fiber-matrix interface and led to delamination [103]. Three failure modes were recorded under compression along the grain: tearing, folding failure, and propagation of cracks between bamboo laminates [34]. Li et al. [62] investigated how the compression behavior of LBL can be affected by the growth portion of bamboo corresponding to bamboo sourced from a different height portion of the culm (base, middle, top). Three groups of specimens from the lower, middle and upper growth portions were tested and showed a variety of failure modes. For instance, one specimen from the lower growth portion started to fracture from the bottom surface and a splitting occurred in the middle of the cross-section (Fig. 9).

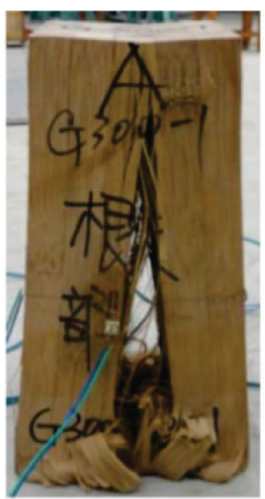

(a)

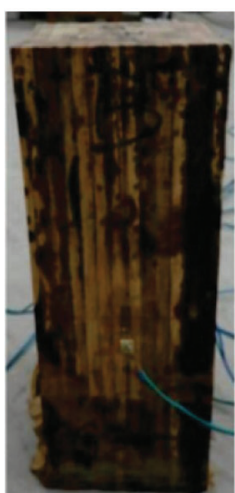

(b)

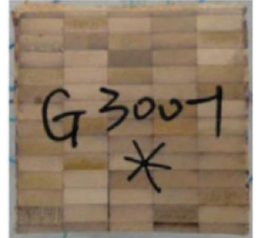

(c)

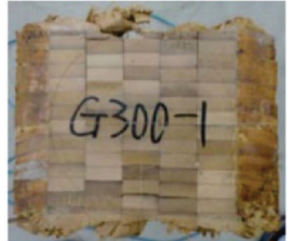

(d)

Figure 9: Failure of LBL from the lower growth portion: (a) face A; (b) face B; (c) top surface; (d) bottom surface (extracted from Li et al. [62] paper)

The specimen from the middle growth portion started to fail from the top surface followed by delamination (Fig. 10).

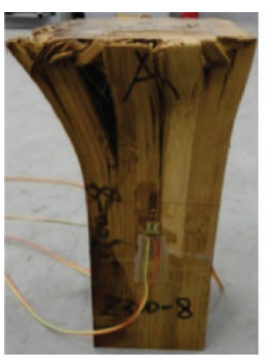

(a)

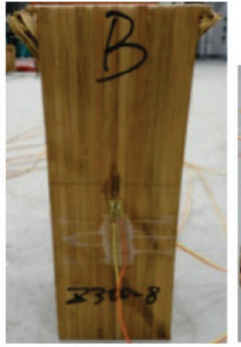

(b)

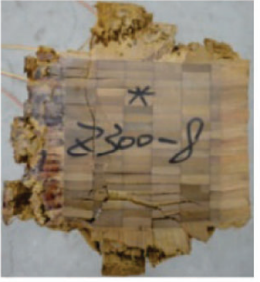

(c)

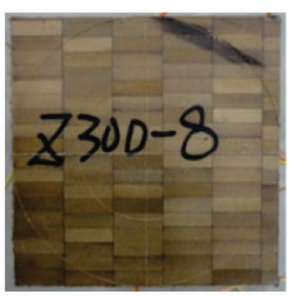

(d)

Figure 10: Failure of LBL from the middle growth portion: (a) face A; (b) face B; (c) top surface; (d) bottom surface (extracted from Li et al. [62] paper)

And the specimen from the upper growth portion failed in shear at $\mathrm{B}$ and $\mathrm{C}$ sides with bending and splitting of A side (Fig. 11).

According to the results, the characteristic compressive strength decreased slightly with growth portion height, and LBL from the middle growth portion exhibited the highest MOE. However, this effect was not significant from a design perspective [62]. According to Verma et al. [52], failure of the LBL specimens 
under compression was caused by micro-buckling surrounded by delamination. Due to the combined growth and deformation, delamination propagated to areas of the laminate that were untouched by the destruction, while the damaged part was enhanced by the deformation. As a result, the specimens completely lost their rigidity (Fig. 12).

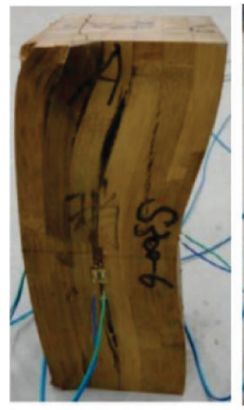

(a)

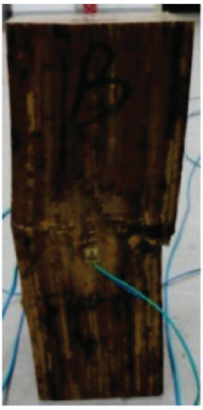

(b)

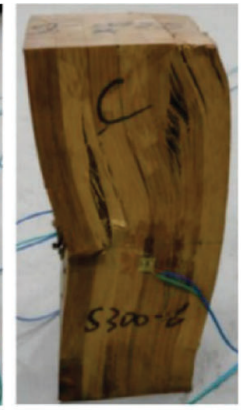

(c)

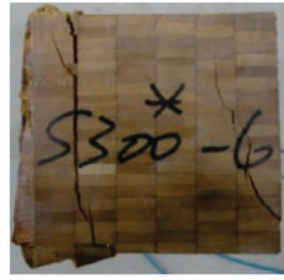

(d)

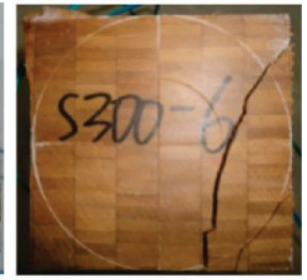

(e)

Figure 11: Failure of LBL from the upper growth portion: (a) face A; (b) face B; (c) face C; (d) top surface; (e) bottom surface (extracted from Li et al. [62] paper)

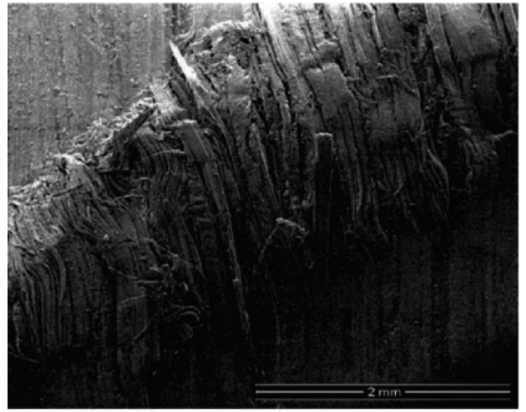

(a)

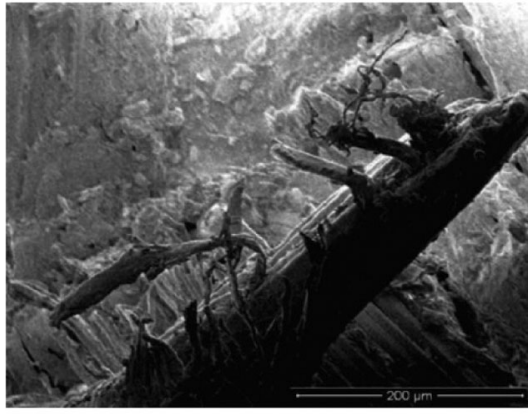

(b)

Figure 12: The SEM photographs $72 x(a)$ and $600 x(b)$ of the fractured lateral surface of specimens tested in compression (extracted from Verma et al. [52] paper)

Takeuchi et al. [63] examined the elastic modulus and the Poisson's ratio and concluded that LBL's physical anisotropy caused an anisotropic mechanical performance. Under compression in both directions, LBL demonstrated the linear elastic stage, elastic-plastic stage, the descending stage [52,64-66,101]. A tri-linear model was proposed to express the stress-strain relationship for LBL under compression (Fig. 13).

According to Fig. 14, the compressive strength parallel to grain did not change strictly between LBL made of strips with different grades and varied from 29.5 to $40.8 \mathrm{MPa}$ [55].

Ameh et al. [60] also pointed out the difference in mechanical properties considering the segment of bamboo and figured out the decrease in compression strength from the bottom to the top bamboo segment with values $31.39 \mathrm{MPa}, 29.38 \mathrm{MPa}$, and 24.99 $\mathrm{MPa}$, respectively.

According to Sulastiningsih et al. [61], the presence of nodes in bamboo strips decreased the compression strength of LBL since the vascular cells of the node were more complicated than the internode. With an increase from the inner to outer regions and in height of bamboo culms the compressive strength and MOE of LBL also increased [56]. Tab. 4 shows the comparison of mechanical 
properties of LBL small specimens under compression compared to other bamboo- and wood-based materials.

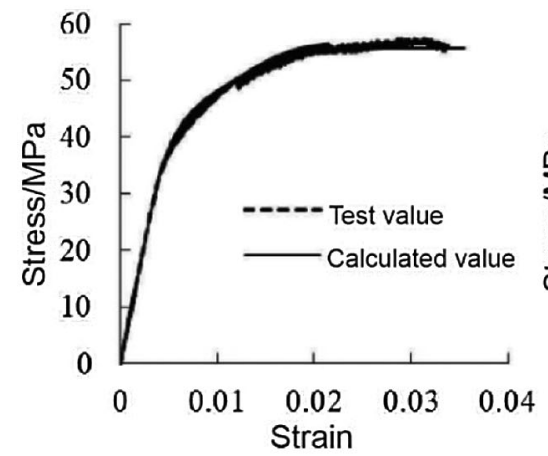

(a)

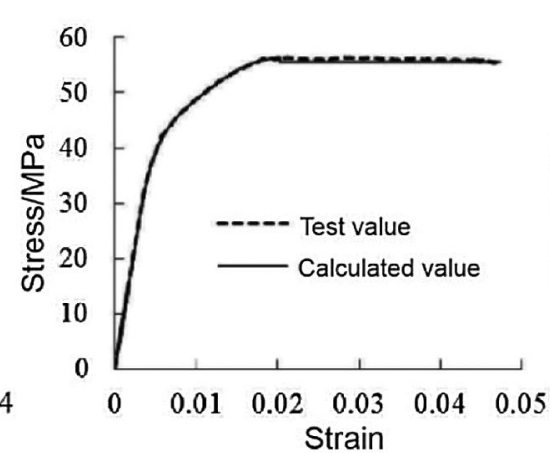

(b)

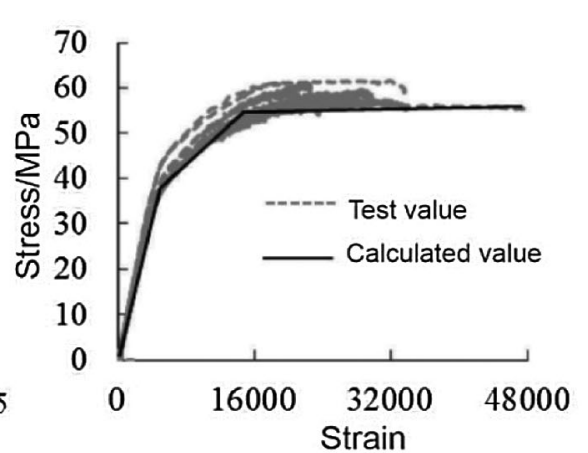

(c)

Figure 13: Stress-strain relationship in LBL under compression: (a) the elastic-perfectly plastic model; (b) the elastoplastic model with curved region; (c) the elastic-elastoplastic-plastic model (extracted from Li et al. [66] paper)

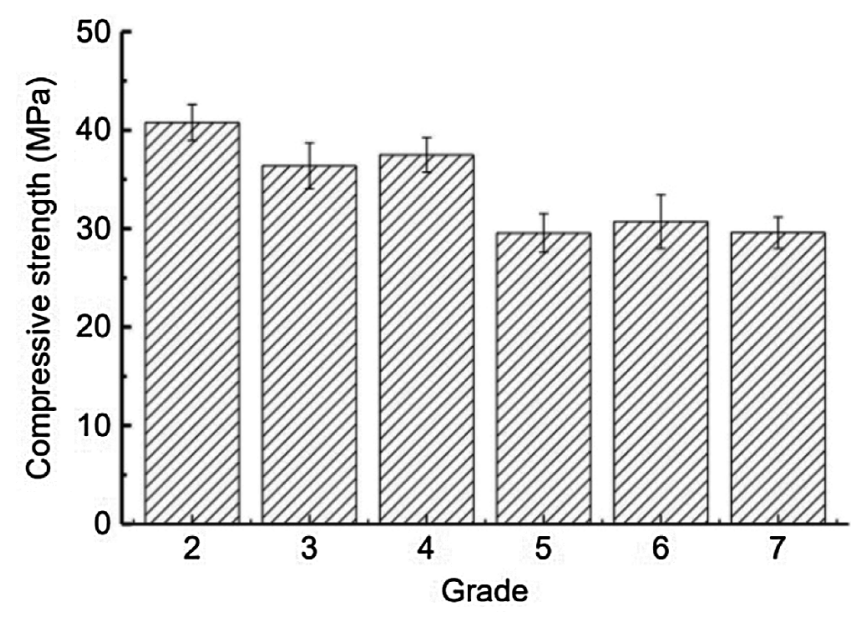

Figure 14: Compressive strength of different grades of LBL (extracted from Ni et al. [55] paper)

As can be seen, the compressive strength of LBL parallel to grain surpasses that of glulam, LVL, WPC, plywood, OSB, and is comparable to similar bamboo-based materials, softwoods, and hardwoods like glubam, bamboo scrimber, Douglas-fir, and teak wood. The variability of the longitudinal compressive strength of LBL is attributed to different density grades or growth portions of bamboo strips corresponding to bamboo sourced from a different height portion of the culm. Compressive strength perpendicular to grain of LBL appeared to be higher than that of softwood, glulam, and LVL, and similar to that of bamboo-based materials and WPC. At the same time, the MOE of LBL is comparable to glulam and other bamboo-based materials.

\subsection{Tension}

A material breakdown under tensile load parallel to grain was characterized as brittle behavior caused by the breakage of fibers $[34,103]$. The LBL specimens in tension parallel to grain exhibited 3 failure modes, 
and all of them fractured in the cross-section: a flat fracture that split the specimens (Mode 1), "Z-type" fracture (Mode 2), and inclined fracture caused by cracks appearance along the fiber direction (Mode 3) (Fig. 15) [34,67].

Table 4: Compression performance of LBL material compared to similar bamboo- and wood-based materials

\begin{tabular}{|c|c|c|c|c|c|c|}
\hline Material & Species & Size, $\mathrm{mm}$ & $\begin{array}{l}\text { Compression II, } \\
\mathrm{MPa}\end{array}$ & $\begin{array}{l}\text { Compression } \\
\perp, \mathrm{MPa}\end{array}$ & MOE ॥, MPa & $\begin{array}{l}\mathrm{MOE} \perp, \\
\mathrm{MPa}\end{array}$ \\
\hline LBL $[34,55,62]$ & $\begin{array}{l}\text { Phyllostachys } \\
\text { pubescens }\end{array}$ & $\begin{array}{l}50 \times 50 \times 200 \\
17 \times 17 \times 50 \\
100 \times 100 \times \\
300\end{array}$ & $29.55-72.60$ & 20.5 & $8396-11022$ & 1853.9 \\
\hline LLBC $[52,96]$ & $\begin{array}{l}\text { Dendrocalamus } \\
\text { strictus }\end{array}$ & $\begin{array}{l}5 \times 16 \times 120 \\
5 \times 16 \times 120\end{array}$ & 67 & - & 14060 & - \\
\hline PSB $[103,104]$ & $\begin{array}{l}\text { Phyllostachys } \\
\text { pubescens }\end{array}$ & $\begin{array}{l}50 \times 50 \times 200 \\
105 \times 105 \times \\
315\end{array}$ & $61.76-65.53$ & 23.14 & $11890-12630$ & 1365 \\
\hline Glubam [93] & - & - & 51 & - & - & - \\
\hline $\begin{array}{l}\text { Bamboo } \\
\text { scrimber [99] }\end{array}$ & $\begin{array}{l}\text { Phyllostachys } \\
\text { pubescen }\end{array}$ & $\begin{array}{l}105 \times 105 \times \\
315\end{array}$ & 86 & 37 & - & - \\
\hline LVL $[34,105]$ & Douglas-fir & - & 36 & 5.17 & - & - \\
\hline Glulam [106] & - & - & $24-31$ & $2.7-3.6$ & 8600 & - \\
\hline WPC [102] & Pine & $20 \times 20 \times 60$ & 28.1 & 25.4 & 3700 & 1980 \\
\hline Plywood [96] & - & - & $20.7-34.5$ & - & - & - \\
\hline OSB [96] & - & - & $10.3-17.2$ & - & - & - \\
\hline Douglas-fir [100] & & - & 49.9 & 5.5 & - & - \\
\hline Teak [100] & & - & 41.1 & - & - & - \\
\hline
\end{tabular}

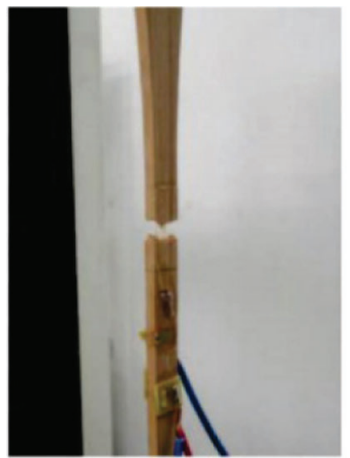

(a)

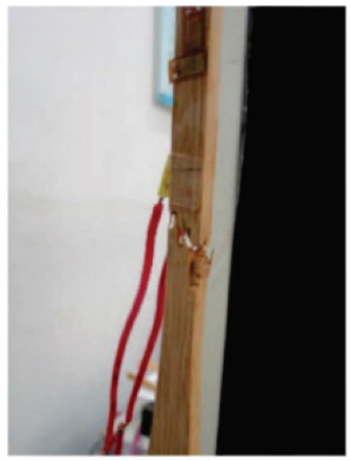

(b)

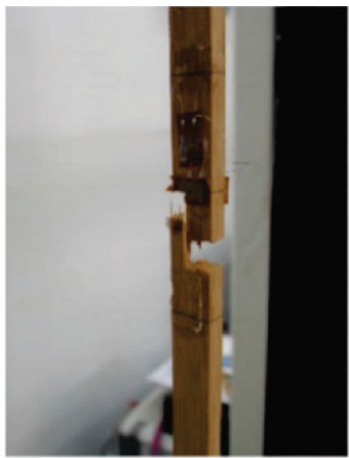

(c)

Figure 15: Failure modes for typical LBL specimens under tension: (a) Mode 1; (b) Mode 2; (c) Mode 3 (extracted from Chen et al. [34] paper) 
The LBL specimens in tension perpendicular to grain showed cracks in different locations, and the failure happened through the bamboo itself and not through the adhesive (Fig. 16) [68,99]. It should be noted, that the tension strength perpendicular to grain of the bamboo was about 40 times lower than the tension strength parallel to grain $[68,99]$.

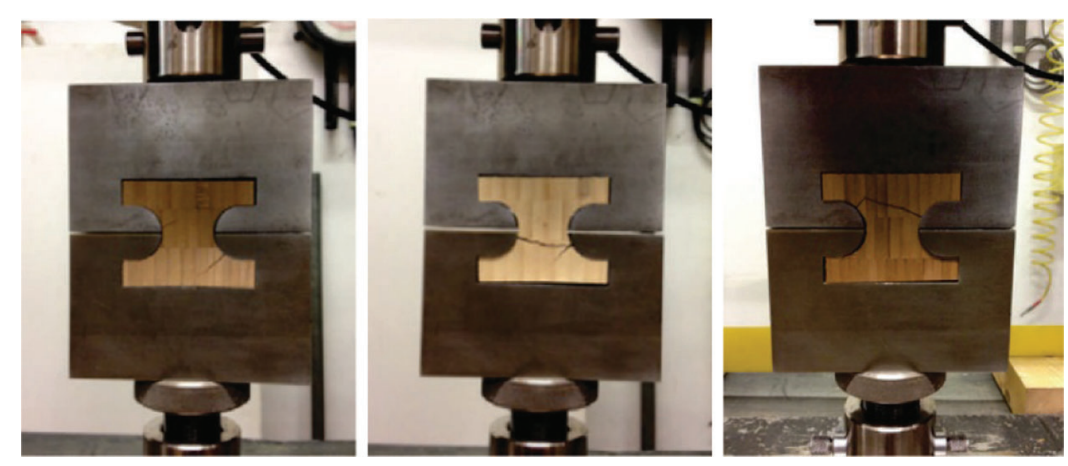

Figure 16: Failure modes of LBL in tension perpendicular to grain (extracted from Sharma et al. [68] and Sharma et al. [99] paper)

According to Verma et al. [52], under tension along the grain, the specimens fractured at various locations such as edges, grips, and multimode. The fracture of LBL started at the matrix of bamboo and adhesive first, and then the fibers broke spontaneously with a metallic sound. Huang et al. [103] also mentioned that the damages took place in a matrix or fiber-matrix interface without involving fibers. The SEM photographs (Figs. 17a and 17b) show the crack propagation of the fractured lateral surface, and it can be seen that the fibers were pulled out since the bonding between bamboo and adhesive was strong.

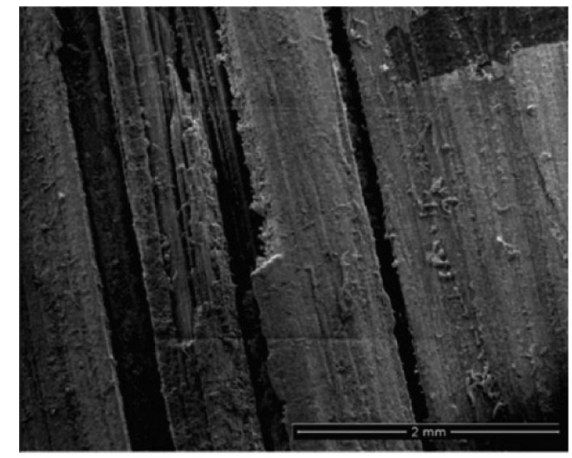

(a)

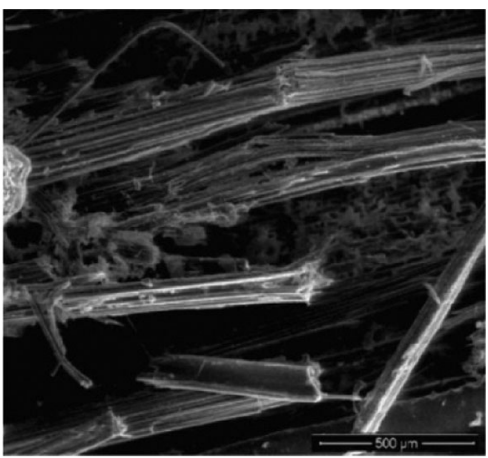

(b)

Figure 17: The SEM photographs 70x (a) and 180x (b) of the fractured lateral surface of specimens under tensile loading (extracted from Verma et al. [52] paper)

Under tension parallel to grain, LBL exhibited perfect linear behavior from loading to failure and suddenly broke when the load reached the ultimate peak without plastic deformation [34,103]. Figs. 18a and $18 \mathrm{~b}$ shows the typical stress-strain curves for LBL under tension parallel and perpendicular to grain.

The stress-strain relationships of LBL under tension parallel to grain can be expressed by linear functions concerning the strains with the slope of corresponding MOE and zero constant items [103]. In perpendicular to grain direction, the tensile modulus was more than two times that of compression, but the strength of tension was much lower than that of compression $[23,103]$. 


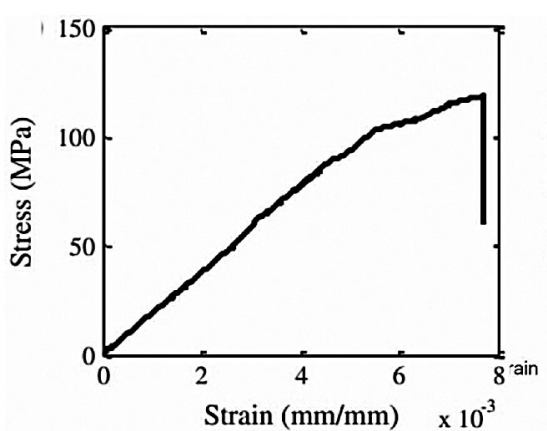

(a)

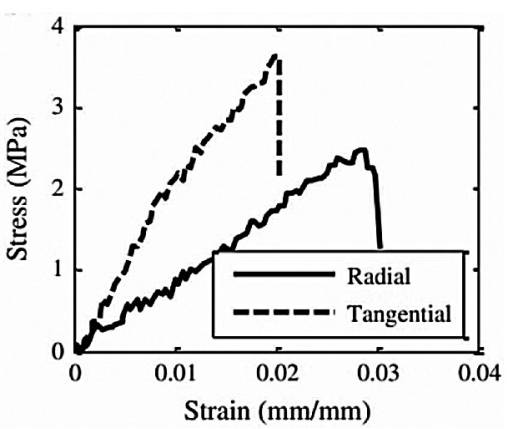

(b)

Figure 18: Stress-strain behavior of LBL in tension: (a) parallel to grain, (b) perpendicular to grain (extracted from Correal et al. [51] paper)

According to Sharma et al. [35], the strength and MOE of the flatwise orientation of LBL under tension perpendicular to grain were higher than that of edgewise by $10 \%$, constituting 4.2-4.3 MPa and 1346-1443 MPa vs. 3.4-3.8 MPa and 1279-1295 MPa, respectively. While in tension parallel to grain, the same parameters constituted 39.1-50 MPa and 8062-8713 MPa, respectively. The authors noted, that the wider distance between joints increased the strength of the specimens.

It should be noted, that butt joints decreased the tensile strength of LBL similar to knots in wooden materials [55]. Due to the unpredictable behavior of nodes and joints, failure of LBL could be initiated by both [54]. As shown in Fig. 19, the fracture of the tensile specimen started in the outmost part of the edge but joint (Figs. 19a and 19d) followed by propagation of the crack (Figs. 19b and 19e) and destruction of the specimen (Figs. 19c and 19f).

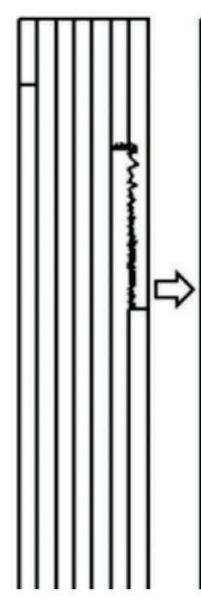

(a)

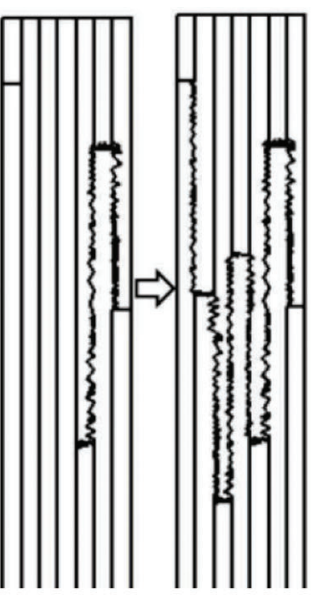

(b)

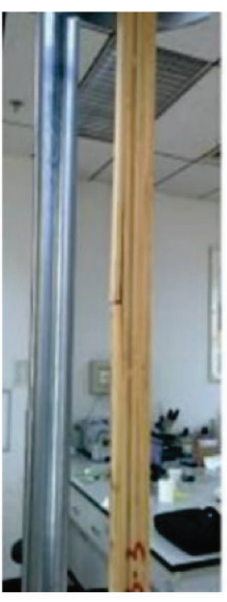

(d)

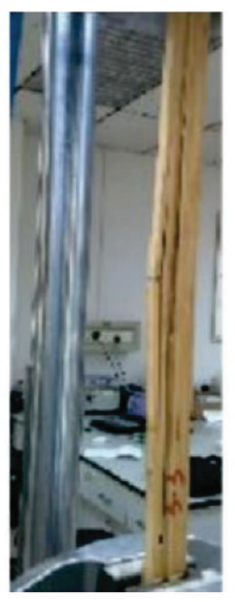

(e)

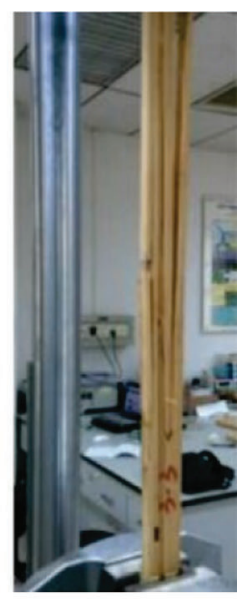

(f)

Figure 19: Failure propagation of the tension specimen with butt joints (extracted from Ni et al. [55] paper)

According to Fig. 20, the grading system based on the density of the strips (Tab. 2) should be taken into consideration for the manufacturing of LBL since the tensile strength of LBL increased with the increase in density [55].

According to previous studies [56,69,70], the tensile strength and MOE of LLBC glued with epoxy increased from the inner to outer region and with the height of bamboo culm with values from 
237.93 MPa to 300.9 MPa and 14.63 GPa to $16.27 \mathrm{GPa}$, respectively. In sum, the tensile strength parallel to grain of small LBL specimens from reviewed studies constituted 89.99-205 MPa, while perpendicular to grain it was 2-3 MPa. The MOE in parallel to grain constituted $10700 \mathrm{MPa}$. Tab. 5 shows the comparison of tensile properties of LBL with bamboo- and wood-based materials.

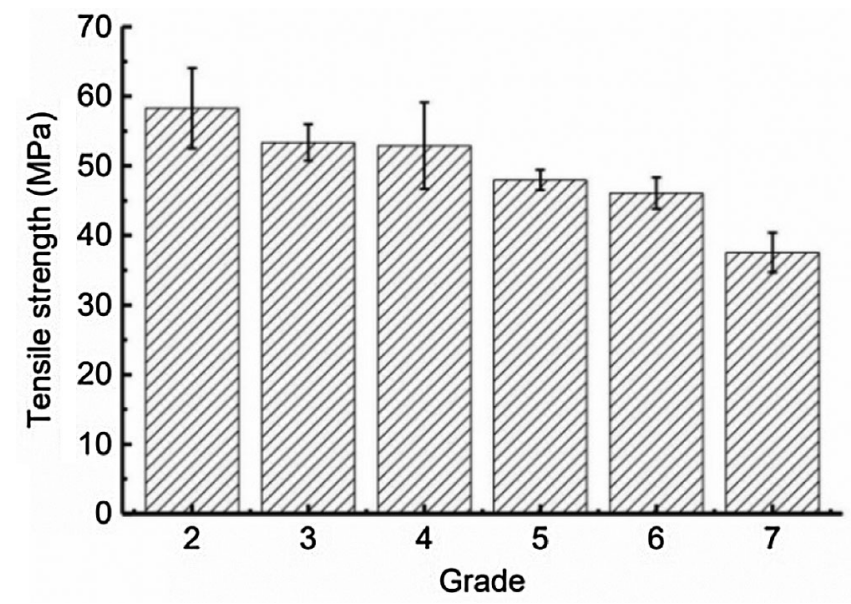

Figure 20: Tensile strength of different grades of LBL (extracted from Ni et al. [55] paper)

Table 5: Properties of LBL in tension compared to bamboo- and wood-based materials

\begin{tabular}{|c|c|c|c|c|c|c|}
\hline Material & Species & Size, $\mathrm{mm}$ & $\begin{array}{l}\text { Tension } \|, \\
\mathrm{MPa}\end{array}$ & $\begin{array}{l}\text { Tension } \perp \text {, } \\
\mathrm{MPa}\end{array}$ & MOE ॥, MPa & $\begin{array}{l}\mathrm{MOE} \perp, \\
\mathrm{MPa}\end{array}$ \\
\hline LBL $[34,68,97]$ & $\begin{array}{l}\text { Phyllostachys } \\
\text { pubescens } \\
\text { Dendrocalamus } \\
\text { strictus }\end{array}$ & $\begin{array}{l}25 \times 50 \times 453 \\
25 \times 25 \times 460 \\
62 \times 50 \times 50\end{array}$ & $90-124$ & $2-3$ & 10700 & - \\
\hline LLBC $[52,96]$ & $\begin{array}{l}\text { Dendrocalamus } \\
\text { strictus }\end{array}$ & $\begin{array}{l}10 \times 16 \times 250 \\
1.5 \times 15 \times 200\end{array}$ & 187.3 & - & 14900 & - \\
\hline PSB $[103,104]$ & $\begin{array}{l}\text { Phyllostachys } \\
\text { pubescens }\end{array}$ & $\begin{array}{l}9.5 \times 25 \times 453 \\
8 \times 19 \times 250\end{array}$ & $118.40-138$ & 4.43 & $10296-13680$ & 3066 \\
\hline Glubam [93] & - & - & 82 & - & 10400 & 2600 \\
\hline $\begin{array}{l}\text { Bamboo scrimber } \\
{[99,107]}\end{array}$ & $\begin{array}{l}\text { Phyllostachys } \\
\text { pubescens }\end{array}$ & $\begin{array}{l}25 \times 25 \times 460 \\
50 \times 50 \times 62\end{array}$ & 120 & 3 & $13500-32300$ & - \\
\hline LVL $[34,105]$ & Douglas-fir & - & 88.5 & 0.83 & 13790 & - \\
\hline Glulam [106] & - & - & $16.5-26$ & $0.4-0.6$ & 9400-11900 & $390-490$ \\
\hline WPC [102] & Pine & - & 11.6 & 5.3 & 3000 & 1500 \\
\hline Plywood [96] & - & - & $10.3-27.6$ & - & - & - \\
\hline OSB [96] & - & - & $6.9-10.3$ & - & - & - \\
\hline Douglas-fir [100] & & - & 107.6 & 2.3 & $11.6-14.8$ & - \\
\hline Teak wood [52] & & - & $95-155$ & - & - & - \\
\hline
\end{tabular}


As can be seen, the longitudinal tensile strength and MOE of LBL are similar to other bamboo- and wood-based materials, hardwoods, and softwoods. A similar LLBC material glued with epoxy and coldpressed appeared to have higher tensile strength and MOE. In tension perpendicular to grain, LBL's strength is still comparable to bamboo-based materials and Douglas-fir and surpasses wood-based materials such as glulam and LVL.

\subsection{Shear}

Both shear parallel and perpendicular to grain of LBL showed a crack along the loading direction and the specimen failed through the bamboo fibers $[68,99,103]$. This can be explained by the higher shear resistance of an adhesive that was bonding the bamboo laminates compared to that of bamboo laminates [34]. Sharma et al. [68] compared the mechanical performance of bleached and caramelized bamboo and concluded, that both specimens exhibited the same failure mode regardless of the treatment type (Fig. 21), and caramelization increased the average shear strength of LBL compared to bleached specimens.

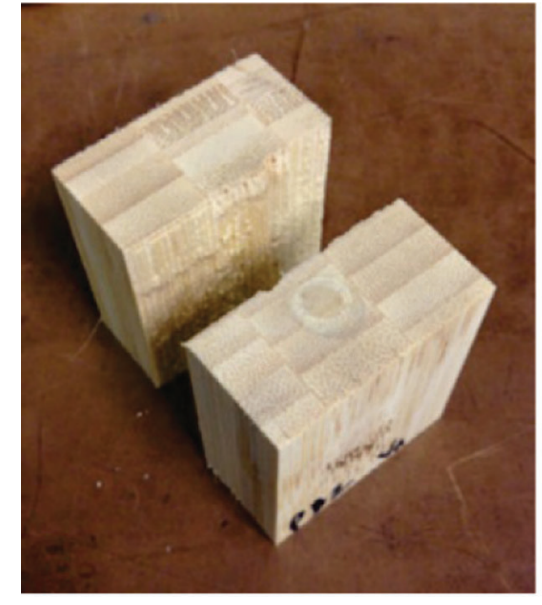

(a)

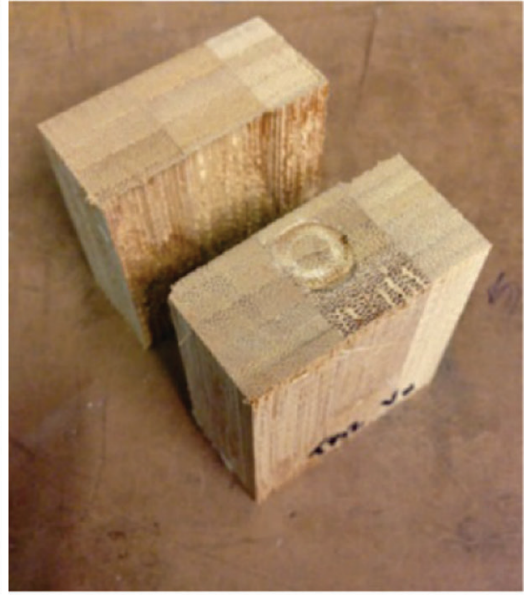

(b)

Figure 21: Failure modes in shear parallel to grain: (a) for bleached LBL, (b) for caramelized LBL (extracted from Sharma et al. [68] paper)

Both the stress-strain relationships of bleached and caramelized LBLs in shear parallel to grain direction were nearly identical [68], and shear stress-displacement curves exhibited elastic properties until the ultimate shear stress was reached [34].

Takeuchi et al. [71] investigated the failure mechanics of LBL with different fiber directions under shear. According to test results, LBL with fibers parallel to the loading direction exhibited a crack that matches with the reduced area plane (Fig. 22a), while in LBL with fibers perpendicular to the loading direction that does not cross the reduced area plane, the crack was inclined $45^{\circ}$ to the loading direction (Fig. 22b). In LBL with fibers perpendicular to the loading direction and crossing the reduced area plane, several cracks were made up perpendicularly to the loading direction and parallel to the fiber orientation (Fig. 22c).

The authors proposed a finite element model (FEM) based on the continuum strong discontinuity approach for composite materials and the Weibull probability model for the prediction of fibers failure. As seen from Figs. 22d-22f, the numerical simulation patterns repeated the crack propagation of the test results, regardless of the slats arrangements. 


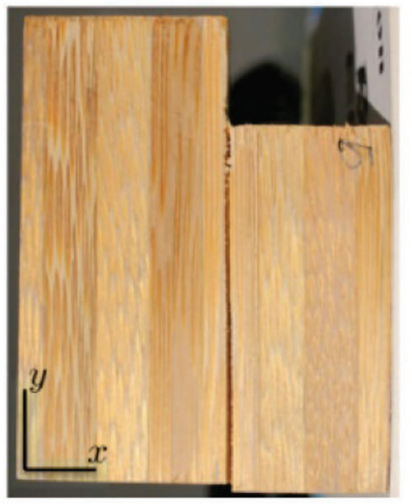

(a)

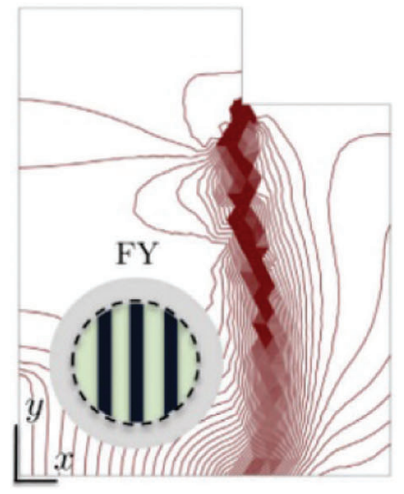

(d)

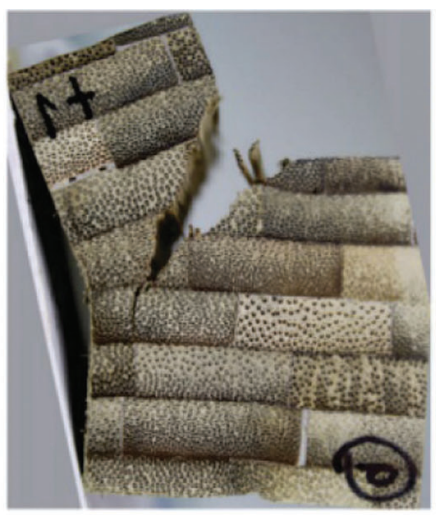

(b)

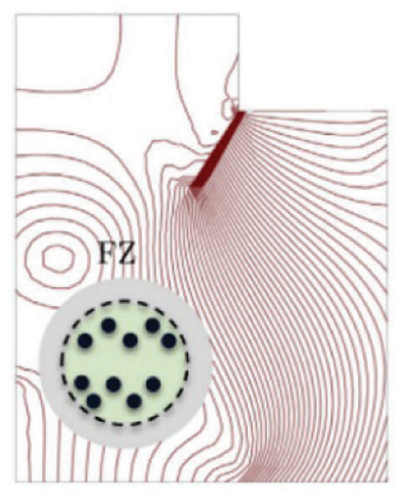

(e)

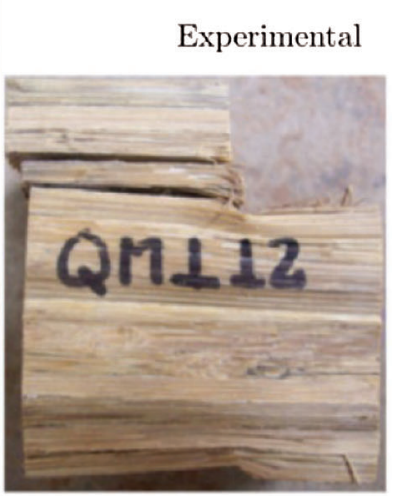

(c)

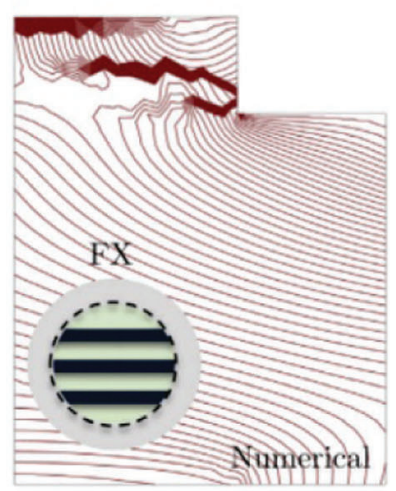

(f)

Figure 22: Comparison of crack pattern between experimental test and numerical simulation: (a, d) Configuration set FY; (b, e) Configuration set FZ; and (c, f) Configuration set FX (extracted from Takeuchi et al. [71] paper)

According to Fig. 23, shear strength didn't change significantly between the LBL made of strips with different grades (Tab. 2).

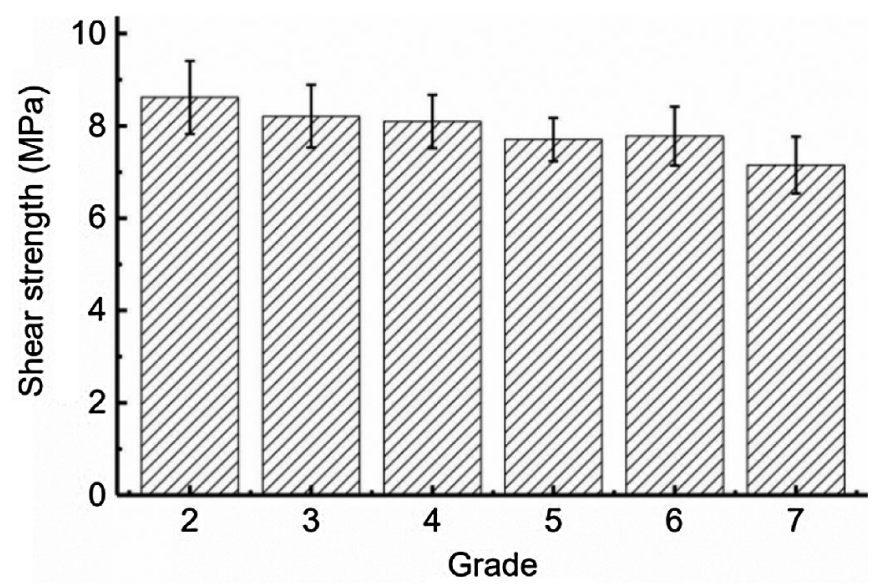

Figure 23: Shear strength of different grades of LBL (extracted from Ni et al. [55] paper) 
However, the strip's orientation affected the shear strength of the specimens, being twice as large in edgewise as in flatwise [35]. Based on reviewed studies, the shear strength parallel to the grain of small LBL specimens constituted 7.15 to $17.5 \mathrm{MPa}$, depending on the density of strips, strip arrangement, and treatment. Tab. 6 shows the comparison of shear properties of LBL with bamboo- and wood-based materials.

Table 6: Properties of LBL in shear compared to bamboo- and wood-based materials

\begin{tabular}{lllll}
\hline Material & Species & Size, mm & Shear I, MPa & Shear $\perp$ MPa \\
\hline LBL [34,55,68,97] & $\begin{array}{l}\text { Phyllostachys } \\
\text { pubescens }\end{array}$ & $\begin{array}{l}50 \times 50 \times 62 \\
17 \times 50 \times 50\end{array}$ & $7.15-17.5$ & - \\
& $\begin{array}{l}50 \times 50 \times 50 \\
\text { Phyllostachys } \\
\text { pubescens }\end{array}$ & $56 \times 76$ & 23.44 & 8.21 \\
PSB [103,104] & - & $40 \times 50 \times 50$ & 16.9 & 17.5 \\
Glubam [76] & $\begin{array}{l}\text { Phyllostachys } \\
\text { pubescens }\end{array}$ & $50 \times 50 \times 50$ & 15 & - \\
Bamboo scrimber [99] & Douglas-fir & $45 \times 200 \times$ & 7.34 & - \\
LVL [107] & - & - & $2.7-4.3$ & - \\
Glulam [105] & Pine & - & 8.1 & 7.1 \\
WPC [102] & & - & 7.8 & - \\
Douglas-fir [100] & & - & 8.9 & - \\
Teak [100] & & & & \\
\hline
\end{tabular}

As can be seen, LBL has a similar shear strength parallel to grain compared to bamboo-based materials such as bamboo scrimber and glubam, and wood-based materials like LVL, WPC, Douglas-fir, and teak. The variability of values can be explained by the effects of processing methods, strip orientations, and density.

\section{Discussion}

This paper presents a review of published studies that are focused on the mechanical performance of LBL to give an understanding of the basic mechanical properties under various loading conditions. According to the literature reviewed, mature bamboo culms of the genera Phyllostachys, Dendrocalamus, Bambusa, Guadua, and Gigantochloa are mostly used for the production of LBL. Compared to wood, bamboo is characterized by a high rate of growth and yield. Despite the relatively low environmental impact in contrast to conventional building materials, the production of LBL consumes more energy than the manufacture of wood-based materials and produces more emissions due to the use of nonenvironmentally friendly adhesives and electricity, which is responsible for $60 \%$ of total pollution. The environmental impact from LBL processing is higher in regions where bamboo does not grow since the energy which is necessary for raw material transportation from bamboo harvesting sites to LBL production sites is added to the total resource consumption. Therefore, the most optimal option is the production of LBL in the places of the original growth of bamboo. In addition, the price of LBL is much higher than that of conventional materials. These reasons call for the development of new cost-saving and low-energy methods for the production of LBL using adhesives without urea and other substances that cause eutrophication, ozone depletion, and acidification. Another disadvantage of LBL production is the occurrence of cracks due to the flattening of bamboo culms to produce a bamboo sheet. Therefore, the optimization of LBL processing methods including split-squaring, v-grooving, and split-edging remains necessary. 
Considering the similarity between LBL and timber, the reviewed studies relied on existing national and international standards for wood and wood composites as ASTM, ISO, and the Chinese state standards. In 2013, the ASTM D5456 was introduced, which included LBL (called laminated veneer bamboo) and presented it as a material similar to wood composites such as laminated strand lumber, laminated veneer lumber, oriented strand lumber, and parallel strand lumber. Due to the growing demand for bamboo-based materials and the development of new bamboo products, the investigation of their physical and mechanical properties is still ongoing. Therefore, new findings and optimized models for predicting the mechanical behavior and criteria for calculating LBL elements in the design based on modern timber standards and proposed by investigations should be displayed in updated versions of the standard. The use and optimization of wood-based test methods for determining the characteristics and design remain relevant, which in turn make it possible to create a foundation for the comprehensive standardization of bamboo structural materials similar to those used for wood.

Based on results of the literature reviewed, the strength of LBL parallel to grain was 90-124 MPa with MOE of $10700 \mathrm{MPa}$ in tension, 29.55-72.60 MPa, and MOE of 8396-11022 MPa in compression, 63.87128.4 MPa, and MOE of $8320-10912 \mathrm{MPa}$ in bending, and 7.15-17.5 MPa in shear. The variability in strength values of LBL can be explained by the effect of density and thickness of bamboo strips, location in culm, growth portion, type of treatment, strips arrangements on the mechanical performance, which in turn calls for classification of LBL by strength grades, degree of hardness, resistance to rot, the capability of impregnation and penetration, as well as by areas of application in construction. The influence of processing methods on the bonding strength of laminas, as well as on the physical properties of the material, also calls for further investigation to determine the types of structural applications. According to reviewed research, the mechanical characteristics of LBL were improved by using laminas sourced from the outer part of the culm, as well as with an increase in the growth portion and the density of the lamina. These and other bamboo-based factors provided the base for the development of structural design values for LBL. Also, some studies have indicated a relationship between the physical and mechanical characteristics of LBL and factors such as bamboo species, the type of adhesive, and the glue spread rate used for the production. Some adhesives turned out to be unsuitable for the production of full-sized LBL and exterior applications, such as EPI and PVA, respectively. At the same time, LBL created with PF and MUF adhesives had the best mechanical characteristics. Therefore, further investigation on the effect of species type considering processing methods, the type of adhesive, and glue spread rate on the behavior of LBL remains relevant. It should be noted that clamping pressures had no significant effects on the bonding shear strength of LBL, but a wider range of clamping pressures should be verified.

Despite the impressive mechanical properties, the nodes and joints significantly reduce the strength of LBL, since they are weak parts of the material and cause its destruction. Nevertheless, the presence of nodes has a good effect on the dimensional stability of LBL and its resistance to thickness swelling.

\section{Conclusion}

In light of the modern trend of sustainability, LBL is a promising alternative to traditional building materials due to its environmental compatibility and competitive physical and mechanical characteristics. Despite the intensity and high cost of production, as well as the influence of nodes and joints on the reduction of mechanical characteristics, the average strength of LBL under various types of loading was similar and in some cases exceeded the average values of bamboo- or wood-based materials, while the variability of its mechanical parameters was lower. The mechanical performance of LBL comparable with other bamboo and wood-based materials, as well as the ability to create elements of various sizes and shapes, makes it a confident alternative to traditional materials as furniture or decoration in interior and exterior applications, as well as structural elements in buildings and bridges. However, this material has not yet been fully investigated, and the existing results of research on its physical and mechanical 
characteristics still call for classification and standardization, which will help practitioners around the world to choose the LBL material considering the bamboo species, adhesive type, processing method and strength class required for the intended end-use.

Funding Statement: The research work presented in this paper is supported by the National Natural Science Foundation of China (Nos. 51878354 \& 51308301), the Natural Science Foundation of Jiangsu Province (Nos. BK20181402 \& BK20130978), Six Talent Peak High-Level Projects of Jiang su Province (No. JZ029), and Qinglan Project of Jiangsu Higher Education Institutions. Any research results expressed in this paper are those of the writers and do not necessarily reflect the views of the foundations.

Conflicts of Interest: The authors declare that they have no conflicts of interest to report regarding the present study.

\section{References}

1. Zhao, X., Huang, Y., Fu, H., Wang, Y., Wang, Z. et al. (2021). Deflection test and modal analysis of lightweight timber floors. Journal of Bioresources and Bioproducts, 6(3), 266-278. DOI 10.1016/j.jobab.2021.03.004.

2. Ding, Y. W., Zhao, X. Y., Wang, Z., Li, M. M., Sayed, U. et al. (2021). Research on impact sound insulation performance of timber floor structure. Experimental Techniques. DOI 10.1007/s40799-021-00440-w.

3. Huang, Y., Zhu, H., Dauletbek, A., Wang, Z., Li, M. et al. (2021). Test and analysis of the sound insulation performance of four types of timber structure floors under jumping excitation. Journal of Renewable Materials, 9(4), 829-840. DOI 10.32604/jrm.2021.014610.

4. Zhang, Y., Huang, Y., Wang, Z., Li, M., Adjei, P. (2021). Theoretical calculation and test of airborne sound insulation for wooden building floor. Proceedings of the Institution of Civil Engineers-Structures and Buildings, 1-30. DOI 10.1680/jstbu.20.00081.

5. Ding, Y., Zhang, Y., Wang, Z., Gao, Z., Zhang, T. et al. (2020). Vibration test and comfort analysis of environmental and impact excitation for wooden floor structure. BioResources, 15(4), 8212-8234. DOI $10.15376 /$ biores.

6. Ramirez, F., Correal, J. F., Yamin, L. E., Atoche, J. C., Piscal, C. M. (2012). Dowel-bearing strength behavior of glued laminated guadua bamboo. Journal of Materials in Civil Engineering, 24(11), 1378-1387. DOI 10.1061/ (ASCE)MT.1943-5533.0000515.

7. Arbelaez, J., Correal, J. (2012). Racking performance of traditional and non-traditional engineered bamboo shear walls. Key Engineering Materials, 517, 171-178. DOI 10.4028/www.scientific.net/KEM.517.171.

8. Richard, M., Gottron, J., Harries, K., Ghavami, K. (2016). Experimental evaluation of longitudinal splitting of bamboo flexural components. Proceedings of the Institution of Civil Engineers-Structures and Buildings, 170, 1-10. DOI 10.1680/jstbu.16.00072.

9. Zea Escamilla, E., Archila, H., Nuramo, D., Trujillo, D. (2019). Bamboo: An engineered alternative for buildings in the global south. In: Guedes, M., Cantuaria, G. (Eds.), Bioclimatic architecture in warm climates, pp. 397-414. Cham: Springer.

10. Harries, K., Morrill, P., Gauss, C., Flower, C., Akinbade, Y. et al. (2019). Screw withdrawal capacity of full-culm P. edulis bamboo. Construction and Building Materials, 216, 531-541. DOI 10.1016/j.conbuildmat.2019.05.009.

11. Xiao, Y., Li, L., Yang, R. (2021). Long-term loading behavior of a full-scale glubam bridge model. Journal of Bridge Engineering, 19(9), 1-7. DOI 10.1061/(asce)be.1943-5592.0000600.

12. Sun, L. W., Bian, Y. L., Zhou, A. P. (2020). Study on short-term creep property of bamboo scrimber. Journal of Forestry Engineering, 5(2), 69-75.

13. Wei, X., Chen, F. M., Wang, G. (2020). Flexibility characterization of bamboo slivers through winding-based bending stiffness method. Journal of Forestry Engineering, 5(2), 48-53.

14. Zhou, Y., Huang, Y., Sayed, U., Wang, Z. (2021). Research on dynamic characteristics test of wooden floor structure for gymnasium. Sustainable Structures, 1(1), 000005. 
15. Fu, H., Zhao, X., Adjei, P., Wang, Z., Wu, X. (2021). Study and analysis on sound absorbing and noise reducing performance of timber construction wall based on acoustic spiral matasurface. Wood Research, 66(3), 341-352 DOI 10.37763/wr.1336-4561/.

16. Lee, A. W. C., Chen, G., Tainter, F. H. (2001). Comparative treatability of moso bamboo and southern pine with CCA preservative using a commercial schedule. Bioresource Technology, 7(1), 87-88. DOI 10.1016/S0960-8524 (00)00145-0.

17. Fang, C., Jiang, Z., Sun, Z., Liu, H., Zhang, X. et al. (2018). An overview on bamboo culm flattening. Construction and Building Materials, 171, 65-74. DOI 10.1016/j.conbuildmat.2018.03.085.

18. Khoshbakht, N., Clouston, P. L., Arwade, S. R., Schreyer, A. C. (2018). Computational modeling of laminated veneer bamboo dowel connections. Journal of Materials in Civil Engineering, 30(2), 1-11. DOI 10.1061/(ASCE) MT.1943-5533.0002135.

19. Mahdavi, M., Clouston, P. L., Arwade, S. R. (2011). Development of laminated bamboo lumber: Review of processing, performance, and economical considerations. Journal of Materials in Civil Engineering, 23(7), 1036-1042. DOI 10.1061/(ASCE)MT.1943-5533.0000253.

20. Escamilla, E. Z., Habert, G., Daza, J. F. C., Archilla, H. F., Fernandez, J. S. E. (2018). Industrial or traditional bamboo construction? Comparative Life Cycle Assessment (LCA) of bamboo-based buildings. Sustainability, 10(9), 3096-3019. DOI 10.3390/su10093096.

21. Yu, H. Q., Jiang, Z. H., Hse, C. Y., Shupe, T. F. (2008). Selected physical and mechanical properties of moso bamboo (Phyllostachys Pubescens). Journal of Tropical Forest Science, 20(4), 258-263.

22. Li, Z., Chen, C., Mi, R., Gan, W., Dai, J. et al. (2020). A strong, tough, and scalable structural material from fastgrowing bamboo. Advanced Materials, 32(10), 1-8. DOI 10.1002/adma.201906308.

23. Huang, Z. R., Chen, Z. F., Huang, D. S., Zhou, A. P. (2016). The ultimate load-carrying capacity and deformation of laminated bamboo hollow decks: Experimental investigation and inelastic analysis. Construction and Building Materials, 117, 190-197. DOI 10.1016/j.conbuildmat.2016.04.115.

24. Jin, X. B., Jiang, Z. H., Wen, X. W., Zhang, R., Qin, D. C. (2017). Flame retardant properties of laminated bamboo lumber treated with monoammonium phosphate (MAP) and boric acid/Borax (SBX) compounds. Bioresources, 12(3), 5071-5085. DOI 10.15376/biores.12.3.5071-5085.

25. Ashraf, M., Jobaer Hasan, M., Al-Deen, S. (2021). Semi-rigid behavior of stainless steel beam-to-column bolted connections. Sustainable Structures, 1(1), 000002.

26. Yang, G., Wang, K. (2020). Evaluation on the application of GLB structures. Journal of Materials Science and Chemical Engineering, 8(5), 21-37. DOI 10.4236/msce.2020.85003.

27. Corbi, O., Baratta, A., Corbi, I., Tropeano, F., Liccardo, E. (2021). Design issues for smart seismic isolation of structures: Past and recent research. Sustainable Structures, 1(1), 000001.

28. Liang, R., Stanislawski, D., Hota, G. (2021). Material characterization and structural response under earthquake loads of hakka rammed earth building. Sustainable Structures, 1(1), 000003.

29. Yu, Y., Huang, X., Yu, W. (2014). A novel process to improve yield and mechanical performance of bamboo fiber reinforced composite via mechanical treatments. Composites Part B: Engineering, 56, 48-53. DOI 10.1016/j. compositesb.2013.08.007.

30. Park, S. H., Jang, J. H., Wistara, N. J., Hidayat, W., Lee, M. et al. (2018). Anatomical and physical properties of Indonesian bamboos carbonized at different temperatures. Journal of the Korean Wood Science and Technology, 46(6), 656-669. DOI 10.5658/wood.2018.46.6.656.

31. Chow, A., Ramage, M. H., Shah, D. U. (2019). Optimizing ply orientation in structural laminated bamboo. Construction and Building Materials, 212, 541-548. DOI 10.1016/j.conbuildmat.2019.04.025.

32. Deng, J. C., Chen, F. M., Li, H. D., Wang, G., Shi, S. Q. (2016). The effect of PF/PVAC weight ratio and ambient temperature on moisture absorption performance of bamboo-bundle laminated veneer lumber. Polymer Composites, 37(3), 955-962. DOI 10.1002/pc.23255.

33. Deng, J. C., Wei, X., Zhou, H. Y., Wang, G., Zhang, S. (2020). Inspiration from table tennis racket: Preparation of rubber-wood-bamboo laminated composite (RWBLC) and its response characteristics to cyclic perpendicular compressive load. Composite Structures, 241, 112135. DOI 10.1016/j.compstruct.2020.112135. 
34. Chen, G., Yu, Y. F., Li, X., He, B. (2020). Mechanical behavior of laminated bamboo lumber for structural application: An experimental investigation. European Journal of Wood and Wood Products, 78(1), 53-63. DOI 10.1007/s00107-019-01486-9.

35. Sharma, B., Bauer, H., Schickhofer, G., Ramage, M. H. (2017). Mechanical characterization of structural laminated bamboo. Proceedings of the Institution of Civil Engineers-Structures and Buildings, 170(4), 250264. DOI 10.1680/jstbu.16.00061.

36. Dauletbek, A., Li, H., Xiong, Z., Lorenzo, R. (2021). A review of mechanical behavior of structural laminated bamboo lumber. Sustainable Structures, 1(1), 000004.

37. Su, J., Li, H., Xiong, Z., Lorenzo, R. (2021). Structural design and construction of an office building with laminated bamboo lumber. Sustainable Structures, 1(2), 000010.

38. Anokye, R., Bakar, E. S., Ratnasingam, J., Yong, A. C. C., Bakar, N. N. (2016). The effects of nodes and resin on the mechanical properties of laminated bamboo timber produced from gigantochloa scortechinii. Construction and Building Materials, 105, 285-290. DOI 10.1016/j.conbuildmat.2015.12.083.

39. Cui, Z., Xu, M., Tu, L., Chen, Z., Hui, B. (2020). Determination of dowel-bearing strength of laminated bamboo at elevated temperatures. Journal of Building Engineering, 30, 101258. DOI 10.1016/j.jobe.2020.101258.

40. Luna, P., Takeuchi, C. (2012). Experimental analysis of frames made with glued laminated pressed bamboo guadua. Novel and Non-Conventional Materials and Technologies for Sustainability, 517, 184-188. DOI 10.4028/www.scientific.net/KEM.517.184.

41. Yang, R. Z., Xiao, Y. (2012). Experimental study of glubam single-bolted joint loaded by tension. Novel and NonConventional Materials and Technologies for Sustainability, 517, 34-42. DOI 10.4028/www.scientific.net/ KEM.517.34.

42. Khoshbakht, N., Clouston, P. L., Arwade, S. R., Schreyer, A. C. (2019). Evaluation of ASTM d5764 dowel connection tests for laminated veneer bamboo (LVB). Journal of Testing and Evaluation, 47(4), 2717-2736. DOI 10.1520/JTE20180385.

43. Reynolds, T., Sharma, B., Harries, K., Ramage, M. (2016). Dowelled structural connections in laminated bamboo and timber. Composites Part B-Engineering, 90, 232-240. DOI 10.1016/j.compositesb.2015.11.045.

44. Tang, Z., Shan, B., Li, W. G., Peng, Q., Xiao, Y. (2019). Structural behavior of glubam I-joists. Construction and Building Materials, 224, 292-305. DOI 10.1016/j.conbuildmat.2019.07.082.

45. Wang, R., Xiao, Y., Li, Z. (2017). Lateral loading performance of lightweight glubam shear walls. Journal of Structural Engineering, 143(6), 4017020. DOI 10.1061/(ASCE)ST.1943-541X.0001751.

46. Wang, R., Wei, S. Q., Li, Z., Xiao, Y. (2019). Performance of connection system used in lightweight glubam shear wall. Construction and Building Materials, 206, 419-431. DOI 10.1016/j.conbuildmat.2019.02.081.

47. Ramage, M., Sharma, B., Bock, M., Gatóo, A., Mulligan, H. (2015). Engineered bamboo: State of the art. Proceedings of the ICE-Construction Materials, 168, 57-67. DOI 10.1680/coma.14.00020.

48. Gatóo, A., Sharma, B., Bock, M., Mulligan, H., Ramage, M. (2014). Sustainable structures: Bamboo standards and building codes. Proceedings of the ICE-Engineering Sustainability, 167, 189-196. DOI 10.1680/ ensu.14.00009.

49. Disén, K., Clouston, P. (2013). Building with bamboo: A review of culm connection technology. Journal of Green Building, 8, 83-93. DOI 10.3992/1943-4618.

50. Li, H. T., Wu, G., Xiong, Z. H., Corbi, I., Corbi, O. (2019). Length and orientation direction effect on static bending properties of laminated moso bamboo. European Journal of Wood and Wood Products, 77(4), 547557. DOI 10.1007/s00107-019-01419-6.

51. Correal, J. F., Echeverry, J. S., Ramírez, F., Luis, E. Y. (2014). Experimental evaluation of physical and mechanical properties of glued laminated guadua angustifolia kunth. Construction and Building Materials, 73, 105-112. DOI 10.1016/j.conbuildmat.2014.09.056.

52. Verma, C. S., Chariar, V. M. (2012). Development of layered laminate bamboo composite and their mechanical properties. Composites Part B-Engineering, 43(3), 1063-1069. DOI 10.1016/j.compositesb.2011.11.065.

53. Li, H. T., Deeks, A. J., Zhang, Q. S., Wu, G. (2016). Flexural performance of laminated bamboo lumber beams. Bioresources, 11(1), 929-943. DOI 10.15376/biores.11.1.929-943. 
54. Jorissen, A. J. M., Voermans, J., Jansen, M. H. (2007). Glued-laminated bamboo: Node and joint failure in bamboo laminations in tension. Journal of Bamboo and Rattan, 6(3-4), 137-144.

55. Ni, L., Zhang, X. B., Liu, H. R., Sun, Z. J., Song, G. N. et al. (2016). Manufacture and mechanical properties of glued bamboo laminates. Bioresources, 11(2), 4459-4471. DOI 10.15376/biores.11.2.4459-4471.

56. Verma, C. S., Purohit, R., Rana, R. S., Mohit, H. (2017). Mechanical properties of bamboo laminates with other composites. Materials Today-Proceedings, 4(2), 3380-3386. DOI 10.1016/j.matpr.2017.02.226.

57. Rusch, F., Trevisan, R., Hillig, E., Mustefaga, E. (2019). Physical-mechanical properties of laminated bamboo panels. Pesquisa Agropecuária Tropical, 49, 2-8. DOI 10.1590/1983-40632019v4953714.

58. Natividad, R., Jimenez Jr., J. (2015). Development of laminated buho [Schizostachyum lumampao (Blanco) merr.] lumber. Philippine Forest Products Journal, 6, 79-89.

59. Noermalicha, S., Nugroho, S. N. (2002). The mechanical properties of curved laminated-bamboo. 7th World Conference on Timber Engineering, vol. 4, pp. 118-120. Faculty of Art and Design, Trisakti University, Indonesia.

60. Ameh, O., Shittu, K. (2021). Laminated bamboo board: A sustainable alternative to timber board for building construction. LAUTECH Journal of Civil and Environmental Studies, 6(1), 104-115. DOI 10.36108/laujoces/.

61. Sulastiningsih, I., Ruhendi, S., Massijaya, M., Darmawan, W., Santoso, A. (2017). Effects of nodes on the properties of laminated bamboo lumber. Wood Research Journal, 4, 19-24. DOI 10.51850/wrj.2013.4.1.19-24.

62. Li, H. T., Zhang, Q. S., Huang, D. S., Deeks, A. J. (2013). Compressive performance of laminated bamboo. Composites Part B-Engineering, 54, 319-328. DOI 10.1016/j.compositesb.2013.05.035.

63. Takeuchi, C., Estrada, M., Linero Segrera, D. (2015). The elastic modulus and poisson's ratio of laminated bamboo guadua angustifolia. Key Engineering Materials, 668, 126-133. DOI 10.4028/www.scientific.net/ KEM.668.126.

64. Correal, J. F., Ramirez, F. (2010). Adhesive bond performance in glue line shear and bending for glued laminated guadua bamboo. Journal of Tropical Forest Science, 22(4), 433-439.

65. Li, H. T., Su, J. W., Zhang, Q. S., Deeks, A. J., Hui, D. (2015). Mechanical performance of laminated bamboo column under axial compression. Composites Part B-Engineering, 79, 374-382. DOI 10.1016/j. compositesb.2015.04.027.

66. Li, H., Zhang, Q., Wu, G. (2015). Stress-strain model of side pressure laminated bamboo under compression. Journal of Southeast University, 45(6), 1131-1133. DOI 10.3969/j.issn.1001-0505.2015.06.019.

67. Estrada, M., Linero, D. L., Takeuchi, C. P. (2019). Numerical model of cracking pattern in laminated bamboo specimens under tensile and shear loads. Frattura ed Integrità Strutturale, 13(48), 348-356. DOI 10.3221/ IGF-ESIS.48.33.

68. Sharma, B., Gatoo, A., Ramage, M. H. (2015). Effect of processing methods on the mechanical properties of engineered bamboo. Construction and Building Materials, 83, 95-101. DOI 10.1016/j. conbuildmat.2015.02.048.

69. Verma, C. S., Chariar, V. M. (2013). Stiffness and strength analysis of four layered laminate bamboo composite at macroscopic scale. Composites Part B-Engineering, 45(1), 369-376. DOI 10.1016/j.compositesb.2012.07.048.

70. Verma, C., Chariar, V., Purohit, R., Aicte, C., Building, J. et al. (2012). Tensile strength analysis of bamboo and layered laminate bamboo composites. International Journal of Engineering Research and Applications (IJERA), 2, 1253-1254.

71. Takeuchi, C. P., Estrada, M., Linero, D. L. (2018). Experimental and numerical modeling of shear behavior of laminated guadua bamboo for different fiber directions. Construction and Building Materials, 177, 23-32. DOI 10.1016/j.conbuildmat.2018.05.040.

72. Bakar, E. S., Nazip, M. N. M., Anokye, R., Hua, L. S. (2019). Comparison of three processing methods for laminated bamboo timber production. Journal of Forestry Research, 30(1), 363-369. DOI 10.1007/s11676018-0629-2.

73. Bakar, E. S., Nugroho, N., Zulfa, U., Maniam, T. (2006). Conversion of bamboo culms into bamboo mat through V-grooving method. Proceedings of 8th Pacific Rim Bio-Based Composites Symposium, Kuala Lumpur, Malaysia. 
JRM, 2022, vol.10, no.2

74. Atienza, A. H., Gutlay, H., Rodrigo, P., Tamayo, P. (2020). Steam integrated flattening machine for bamboo culms. IOP Conference Series: Materials Science and Engineering, 739, 012027. DOI 10.1088/1757-899X/ 739/1/012027.

75. Leng, Y., Xu, Q., Harries, K. A., Chen, L., Liu, K. et al. (2020). Experimental study on mechanical properties of laminated bamboo beam-to-column connections. Engineering Structures, 210, 2-11. DOI 10.1016/j. engstruct.2020.110305.

76. Li, Z., Zhang, J., Wang, R., Monti, G., Xiao, Y. (2020). Design embedment strength of plybamboo panels used for glubam. Journal of Materials in Civil Engineering, 32(5), 1-12. DOI 10.1061/(ASCE)MT.1943-5533.0003128.

77. Li, J., Zhou, A. (2019). Mechanical behavior of laminated bamboo lumber dowel-type connection. Advances in Structural Engineering, 23(1), 65-73. DOI 10.1177/1369433219866091.

78. Sinha, A., Miyamoto, B. T. (2014). Lateral load carrying capacity of laminated bamboo lumber and oriented strand board connections. Journal of Materials in Civil Engineering, 26(4), 741-747. DOI 10.1061/(ASCE) MT.1943-5533.0000848.

79. Sun, Y. H., Jiang, Z. H., Zhang, X. B., Sun, Z. J., Liu, H. R. (2019). Behavior of glued laminated bamboo and bamboo-oriented strand board sheathing-to-framing connections. European Journal of Wood and Wood Products, 77(6), 1189-1199. DOI 10.1007/s00107-019-01454-3.

80. Cui, Z. Y., Tu, L. H., Xu, M., Chen, Z. F., Wang, C. X. (2020). The evaluation of dowel-bearing properties of laminated bamboo parallel to grain. Structures, 25, 956-964. DOI 10.1016/j.istruc.2020.04.004.

81. Xiao, Y., Chen, G., Feng, L. (2014). Experimental studies on roof trusses made of glubam. Materials and Structures, 47(11), 1879-1890. DOI 10.1617/s11527-013-0157-7.

82. Yan, Y., Liu, H. R., Zhang, X. B., Wu, H., Huang, Y. (2016). The effect of depth and diameter of glued-in rods on pull-out connection strength of bamboo glulam. Journal of Wood Science, 62(1), 109-115. DOI 10.1007/s10086015-1516-5.

83. Lou, Z. C., Yang, L. T., Zhang, A. W., Shen, D. H., Li, Y. J. (2020). Influence of saturated steam heat treatment on the bamboo color. Journal of Forestry Engineering, 5(4), 38-44.

84. Lou, Z. C., Yuan, C. L., Shen, D. H., Yang, L. T., Li, Y. J. (2020). Effect of saturated steam treatment on the chemical composition and crystallinity properties of bamboo bundles. Journal of Forestry Engineering, 5(2), $29-35$.

85. Reynolds, T. P. S., Sharma, B., Serrano, E., Gustafsson, P. J., Ramage, M. H. (2019). Fracture of laminated bamboo and the influence of preservative treatments. Composites Part B-Engineering, 174, 107017. DOI 10.1016/j.compositesb.2019.107017.

86. Kadivar, M., Gauss, C., Ghavami, K., Savastano, H. (2020). Densification of bamboo: State of the Art. Materials, 13(19), 4346. DOI 10.3390/ma13194346.

87. Xing, W., Hao, J., Sikora, K. S. (2019). Shear performance of adhesive bonding of cross-laminated bamboo. Journal of Materials in Civil Engineering, 31(9), 2-10. DOI 10.1061/(ASCE)MT.1943-5533.0002854.

88. Teixeira, D. E., Bastos, R. P., Almeida, S. A. D. (2015). Characterization of glued laminated panels produced with strips of bamboo (Guadua magna) native from the Brazilian cerrado. Cerne, 21(4), 495-600. DOI 10.1590/ 01047760201521041893.

89. Sinha, A., Way, D., Mlasko, S. (2014). Structural performance of glued laminated bamboo beams. Journal of Structural Engineering, 140(1), 04013021. DOI 10.1061/(ASCE)ST.1943-541X.0000807.

90. Nugroho, N., Ando, N. (2001). Development of structural composite products made from bamboo II: Fundamental properties of laminated bamboo lumber. Journal of Wood Science, 41(3), 237-242. DOI 10.1007/BF01171228.

91. Lin, Q. Q., Huang, Y. X., Li, X. D., Yu, W. J. (2020). Effects of shape, location and quantity of the joint on bending properties of laminated bamboo lumber. Construction and Building Materials, 230, 2-8. DOI 10.1016/j.conbuildmat.2019.117023.

92. Li, J. Q., Yuan, Y., Guan, X. (2016). Assessing the environmental impacts of glued-laminated bamboo based on a life cycle assessment. Bioresources, 11(1), 1941-1950. DOI 10.15376/biores.11.1.1941-1950. 
93. Xiao, Y., Shan, B., Yang, R. Z., Li, Z., Chen, J. (2014). Glue laminated bamboo (glubam) for structural applications. Materials and Joints in Timber Structures: Recent Developments of Technology, 9, 589-601. DOI 10.1007/978-94-007-7811-5.

94. Mahdavi, M., Clouston, P. L., Arwade, S. R. (2012). A low-technology approach toward fabrication of laminated bamboo lumber. Construction and Building Materials, 29, 257-262. DOI 10.1016/j.conbuildmat.2011.10.046.

95. Jimenez Jr., J., Natividad, R. (2019). Development of arc-laminated bamboo lumber. Philippine Journal of Science, 148, 21-31.

96. Verma, C. S., Sharma, N. K., Chariar, V. M., Maheshwari, S., Hada, M. K. (2014). Comparative study of mechanical properties of bamboo laminae and their laminates with woods and wood based composites. Composites Part B-Engineering, 60, 523-530. DOI 10.1016/j.compositesb.2013.12.061.

97. Zhou, A., Bian, Y., Pacheco-Torgal, F., Belzunce, F. J. (2014). Experimental study on the flexural performance of parallel strand bamboo beams. The Scientific World Journal, 2014, 181627. DOI 10.1155/2014/181627.

98. Li, Z., Yang, G. S., Zhou, Q., Shan, B., Xiao, Y. (2019). Bending performance of glubam beams made with different processes. Advances in Structural Engineering, 22(2), 535-546. DOI 10.1177/1369433218794327.

99. Sharma, B., Gatoo, A., Bock, M., Ramage, M. (2015). Engineered bamboo for structural applications. Construction and Building Materials, 81, 66-73. DOI 10.1016/j.conbuildmat.2015.01.077.

100. Wood Handbook (2010). Wood as an engineering material. USA, Department of Agriculture, Forest Service, Forest Products Laboratory.

101. Marx, C. M., Moody, R. M. (1981). Bending strength of shallow glued-laminated beams of a uniform grade. https://www.fpl.fs.fed.us/documnts/fplrp/fplrp380.pdf.

102. Hugot, F., Cazaurang, G. (2009). Mechanical properties of an extruded wood plastic composite. Mecanique \& Industries, 10(6), 519-524. DOI 10.1051/meca/2010010.

103. Huang, D. S., Bian, Y. L., Zhou, A. P., Sheng, B. L. (2015). Experimental study on stress-strain relationships and failure mechanisms of parallel strand bamboo made from Phyllostachys. Construction and Building Material, 77, 130-138. DOI 10.1016/j.conbuildmat.2014.12.012.

104. Huang, D., Zhou, A., Bian, Y. (2013). Experimental and analytical study on the nonlinear bending of parallel strand bamboo beams. Construction and Building Materials, 44, 585-592. DOI 10.1016/j. conbuildmat.2013.03.050.

105. Zhang, X. L., Que, Y. L., Wang, X. M., Li, Z. R., Zhang, L. L. (2018). Experimental behavior of laminated veneer lumber with round holes, with and without reinforcement. Bioresources, 13(4), 8899-8910. DOI 10.15376/ biores.13.4.8899-8910.

106. Sousa, H. S., Branco, J. M., Lourenco, P. B. (2013). Glulam mechanical characterization. Advanced Materials Forum, 730-732, 994-999. DOI 10.4028/www.scientific.net/MSF.730-732.994.

107. Huang, Y. X., Ji, Y. H., Yu, W. J. (2019). Development of bamboo scrimber: A literature review. Journal of Wood Science, 62(25), 2-10. DOI 10.1186/s10086-019-1806-4. 